NBER WORKING PAPER SERIES

\title{
CORPORATE TAXES AND RETAIL PRICES
}

\author{
Scott R. Baker \\ Stephen Teng Sun \\ Constantine Yannelis \\ Working Paper 27058 \\ http://www.nber.org/papers/w27058
NATIONAL BUREAU OF ECONOMIC RESEARCH
1050 Massachusetts Avenue
Cambridge, MA 02138
April 2020, Revised March 2023

The authors wish to thank John Barrios, Tony Cookson, Anthony DeFusco, Merle Erickson, Alex Frankel, Paolo Fulghieri, George Georgiadis, Joao Granja, Kevin Hassett, Florian Heider, Sabrina Howell, Ankit Kalda, Ryan Kim, Jacob Leshno, Rachel Ma, Neale Mahoney, Mike Minnis, Holger Mueller, Jordan Nickerson, Josh Rauh, Jim Poterba, Rui Silva, Janis Skrastins, Ted LochTemzelides, Michael Weber, Ed Van Wesep, George Zodrow, and Eric Zwick for helpful comments as well as participants at the NBER Meetings on Business Taxation, MIT Sloan School of Management, Stanford University, the Kellogg School of Management, the Carlson School of Management, the Booth School of Business, Rice University, the Gies College of Business, J. Mack Robinson College of Business, the Adam Smith Workshop, the UNC Kenan-Flagler Tax Symposium, the SFS Cavalcade at the Kelley School of Business, the Midwest Finance Association, the SFS Cavalcade Asia-Pacific and the Labor and Finance Group Meetings at the University of Chicago. Mark Zhenzhi He and Sam Earnest provided exceptional research assistance. Researchers' own analyses are derived in part from data from The Nielsen Company (US), LLC and marketing databases provided through the Kilts Center for Marketing Data Center at the Booth School of Business. The conclusions drawn from the Nielsen data are those of the researchers and do not reflect the views of Nielsen or the National Bureau of Economic Research. Nielsen is not responsible for, had no role in, and was not involved in analyzing and preparing the results reported herein.

NBER working papers are circulated for discussion and comment purposes. They have not been peer-reviewed or been subject to the review by the NBER Board of Directors that accompanies official NBER publications.

(C) 2020 by Scott R. Baker, Stephen Teng Sun, and Constantine Yannelis. All rights reserved. Short sections of text, not to exceed two paragraphs, may be quoted without explicit permission provided that full credit, including $(\mathrm{O}$ notice, is given to the source. 
Corporate Taxes and Retail Prices

Scott R. Baker, Stephen Teng Sun, and Constantine Yannelis

NBER Working Paper No. 27058

April 2020, Revised March 2023

JEL No. G38,H22,H25

\section{$\underline{\text { ABSTRACT }}$}

Higher corporate taxes must result in lower payments to shareholders, lower wages, or higher product prices. We study the impact of corporate taxes on barcode-level product prices using linked survey and administrative data. Our empirical strategy exploits the dichotomy between the location of production and the location of sales, providing estimates free from confounding local demand shocks. We find significant effects of corporate taxes on prices with a net-of-tax elasticity of 0.24 . We find null effects on prices for firms subject to personal income taxes or to full sales apportionment. Approximately half of corporate tax incidence falls on consumers, suggesting that models used by policymakers may significantly underestimate the incidence of corporate taxes on consumers. Pass-through is larger for products purchased by high-income households, higher priced goods, and in less competitive markets.

Scott R. Baker

Kellogg School of Management

Northwestern University

2211 Campus Drive

Evanston, IL 60208

and NBER

s-baker@kellogg.northwestern.edu

Stephen Teng Sun

City University of Hong Kong

sunteng2007@gmail.com
Constantine Yannelis

Booth School of Business

University of Chicago

5807 S. Woodlawn Avenue

Chicago, IL 60637

and NBER

constantine.yannelis@chicagobooth.edu 


\section{Introduction}

As an accounting fundamental, higher corporate taxes must result in lower payments to shareholders, lower wages, or higher product prices. The incidence of corporate taxes on workers, consumers and capital is key to debates on tax policy. While a large body of work starting with Harberger (1962) focuses on the incidence of corporate taxes on shareholders, and more recent work has studied the impacts on wages (Fuest, Peichl and Siegloch, 2018; Ljungqvist and Smolyansky, 2016) and avoidance through firm location choices (Giroud and Rauh, 2019; Suárez Serrato and Zidar, 2016), no empirical work has yet examined the effects of corporate tax changes on consumer prices. ${ }^{1}$ While the passage of the 2017 Tax Cuts and Jobs Act instituted the biggest federal corporate tax cut in recent American history, the impact on consumers was unknown - models used by policymakers assume that corporate taxes are fully incident on only capital and labor (CBO, 2018; Cronin, Lin and Powell, 2013).

This paper uses linked administrative and survey data to study the impact of corporate taxes on barcode-level product prices, which is key in evaluating the incidence of corporate taxes on consumers. We present the first estimates of how changes in corporate taxes affect retail prices, finding that taxes levied on producers do impact the final retail sales prices of their products. This finding stands in contrast to early theoretical work which argued that, in a closed economy, corporate taxes should be fully incident on capital (Harberger, 1962) and joins a growing literature that recognizes the effects of corporate taxes on other economic stakeholders. It is important to understand the impacts of corporate taxes on prices paid by consumers even separately from their impacts on real wages and real capital income. This is because many consumers may not be in the labor force or hold capital and thus can be affected by price changes without offsetting changes in income.

We use variation in state-level corporate tax rates over time (as in Heider and Ljungqvist (2015)) to identify the effects of corporate taxes on retail prices. There are two significant challenges in isolating a causal impact through this channel. The first challenge is simply that it has been difficult to assemble a corpus of data with information both on retail prices and the tax nexus

\footnotetext{
${ }^{1}$ Harberger (1962) argued that corporate taxes would be incident on capital in a closed economy. Later works argued that when corporate and non-corporate firms produced the same good, the incidence can fall on labor and consumers (Feldstein and Slemrod, 1980; Gravelle and Kotlikoff, 1989). See Fullerton and Metcalf (2002) and Auerbach (2006) for a review of classic works on the incidence of corporate taxation.
} 
of firms that produce those items. The tax rate in the location where the transaction occurs cannot be relied upon as the applicable rate since firms that produce tradable goods are often located in states other than the states where goods are sold. The second is one of identification: corporate tax changes may be correlated with other factors that determine retail prices. For example, states may be more likely to raise taxes during recessions, when price growth is lower due to lower demand.

To overcome the first empirical challenge and implement our empirical approach, we link several datasets that enable us to observe barcode-level product prices, the location of each item's producers, and the relevant tax rates for each producer. First, and most importantly, we link the Nielsen Retail Measurement Services (RMS) scanner data, a representative sample of retail sales in all major metropolitan areas to barcode data from GS1, the company that assigns an item a Universal Product Code (UPC). This database contains the identity of the firm that produced an item sold and provides us with a link between the firm that produced an item and the item's final retail price across different geographical locations and different retailers. We further identify firm characteristics from the ORBIS database, which contains administrative and ownership data and allows us to determine the relevant corporate tax rates for a producer given the location of its sales and operations. Finally, we assemble corporate tax rate information by using data from Giroud and Rauh (2019), which we extend to 2017 using the same set of sources as they used.

We deal with the challenge of identification by utilizing the fact that if a firm has tax nexus (employees and property) in one state, but sells products in multiple states, then the firm's profits will primarily be subject to the tax laws of the state where the firm has major operations. That is, state-level corporate tax rates are imposed on firms based on the location of their employees, plants, and actual sales. These 'apportionment factors' vary across states. We are able to use tax changes in the states where firms' operations are located to examine the impact on retail prices in other states in which their products are sold (which we refer to as the 'sold-state'). In this manner, we avoid the issue stemming from the endogeneity of local tax changes by exploiting the dichotomy between the location of production and the location of product sales in a similar spirit to Bertrand and Mullainathan (2003).

This approach allows us to include retailer by sold-state by year fixed effects. That is, we can compare items sold within the same retailer in the same state and year, but whose producer firms face different levels of corporate taxation due to their having operations across different states. 
Our fixed effects capture time-varying state-specific shocks to retail prices such as local economic conditions where an item was sold. They also capture time-varying retailer shocks that may affect pricing, such as a national retail chain facing financial distress.

Our empirical approach is motivated by a simple model of corporate tax incidence. We find an elasticity of retail price to the net of corporate tax rates $(1-\tau)$ of approximately 0.24 . This means that a one percentage point increase in the corporate tax rate leads to a 0.24 percent increase in retail product prices. The results remain stable when we include retailer by year, sold-state by year, or retailer by sold-state by year fixed effects. While our data does not contain information to identify the wage effects of corporate taxes, our model and empirical estimates allow for a backof-envelope calculation of the wage elasticity to be 0.3 . This estimate is in line with the point estimates under 0.4 found in Germany by Fuest, Peichl and Siegloch (2018), which serves as a plausibility check for our price effect estimation.

Informed by our empirical estimate, we can gauge the incidence of corporate taxes on consumers by relating the welfare change of consumers induced by a marginal change in the net-oftax rate to the sum of the welfare changes of consumers, workers and firm owners (Suárez Serrato and Zidar, 2016; Fuest, Peichl and Siegloch, 2018). We find the incidence on consumers, workers and shareholders is $52 \%, 28 \%$ and $20 \%$, respectively. This stands in sharp contrast to the case where we do not take into account the effect of corporate income tax on product prices; under this assumption, workers and shareholders will bear $30 \%$ and $70 \%$ of the tax burden, respectively. We complement our main analysis with a graphical event study, using only large changes in corporate taxes. Our analysis indicates that the timing of price changes following tax events reflects the events studied. We see little price movement in the periods immediately before tax events, and we see prices rise or fall following tax increases and cuts.

Additionally, we repeat our analysis using a set of firms that are not subject to corporate taxes: S-corporations (Yagan, 2015). S-corporations belong to another legal form of organization and are required to pay personal income taxes rather than corporate income taxes. If our empirical strategy for identifying the causal effects of corporate tax changes is valid, we should only find price effects of corporate taxes for C-corporations and not for S-corporations. On the other hand, if changes in state corporate income taxes are correlated with unobserved supply-side shocks, then both C-corporations and S-corporations should be affected. We find significant price effects for 
C-corporations seeing corporate income tax rate changes but no effects for tax rate changes that do not affect the legal entity - neither for C-corporations following personal income tax rate changes nor for S-corporations when corporate income tax rates change.

These results are upheld in graphical analyses showing binned scatter plots of changes in retail prices against changes in corporate tax rates for both $\mathrm{C}$-corporations and $\mathrm{S}$-corporations. Consistent with our parametric regression outcomes, we find a strong relationship between corporate taxes and prices for C-corporations but no significant relationship for S-corporations. We conduct several further tests. We show that our results are robust to controlling for various state-level tax credits or grants that might be correlated with changes in corporate tax rates: (1) investment tax credits; (2) upper and lower bounds of R\&D tax credits; (3) job creation tax credit indicators; and (4) job creation grant indicators. We also control for a battery of other fixed effects and find that our main effects persist.

Beyond the average effects of corporate taxes, we demonstrate significant heterogeneous effects across products and firms. We find evidence of a larger effect for UPCs commonly purchased by households with higher incomes relative to those purchased by low-income households and for products that have higher prices. We also find evidence that the tax elasticity of price is smaller in more competitive product markets, which is consistent with demand elasticity being lower in less competitive markets which allows for higher tax pass through (Fullerton and Metcalf, 2002).

Our paper links closely to the literature studying corporate tax incidence. To our knowledge, this is the first modern study to empirically estimate how corporate taxes causally affect retail prices. $^{2}$ Early work starting with Harberger (1962) argued that, in a closed economy, corporate tax incidence is borne almost entirely by capital. However, subsequent work has noted that in open economies business taxes can potentially impact investment and consumer prices (Kotlikoff and Summers, 1987). Gravelle (2013) provides a review of much of the classic literature on corporate tax incidence.

Newer empirical work has focused on the incidence of corporate taxes on firm location choice and workers. Giroud and Rauh (2019) study how corporate taxes impact firm location choices and employment reallocation, comparing S- and C- corporations, while Ljungqvist and Smolyansky

\footnotetext{
${ }^{2}$ For instance, Krzyzaniak and Musgrave (1963) and Krzyzaniak and Musgrave (1968) examine the impact of corporate tax rates on prices for the output of large manufacturers using time series variation in corporate taxes, but were subject to criticisms of reverse causality due to firm level price setting behavior surrounding World War 2.
} 
(2016) study the impact of corporate taxes on regional employment and income. Suárez Serrato and Zidar (2016) estimate the incidence of corporate taxes on workers and owners and find that roughly one-third of corporate taxes are incident on workers. Fajgelbaum, Morales, Suárez Serrato and Zidar (2018) study spatial misallocation, taking into account worker and firm preferences. In an important study, Fuest, Peichl and Siegloch (2018) use German data and find that corporate taxes do indeed affect real wages.

Papers such as Fuest et al. (2018) and Ljungqvist and Smolyansky (2016) investigate impacts of corporate tax changes on real wages, implicitly taking into account some potential effect on prices through inflation adjustments. However, it is important to separately examine the direct impacts of corporate taxes on prices as many households may be consumers but not wage earners or stockholders. Moreover, heterogeneity within the impacts on prices may be important for thinking about consumer welfare and can be missed by representative agent frameworks where agents are equally exposed to price, wage, and capital income changes.

Recent studies have also focused on how corporate taxes impact firm leverage (Heider and Ljungqvist, 2015), risk-taking (Ljungqvist, Zhang and Zuo, 2017) and corporate innovation (Akcigit and Stantcheva, 2020; Akcigit, Grigsby, Nicholas and Stantcheva, 2022). We add to this literature by providing, to our knowledge, the first direct and causal estimates of the effects of corporate taxes on product level retail prices. Following our approach, Dedola et al. (2022) examine the effects of corporate taxes on retail prices in Germany. Given Germany's system of local business rates, they are able to follow our approach of leveraging discrepancies between the locus of business activity for a producer and the location of the sale of their products to identify causal impacts of corporate tax changes on retail prices. They find similar, if somewhat larger, sizes of corporate tax pass-through to prices, especially among supermarket retailers.

Our paper has important implications for the incidence and progressivity of corporate taxes. Due to effects on prices, corporate taxes are more similar to sales taxes in their effects. Many studies of corporate tax incidence ignore the impact on consumers, as do many models used by policymakers. For example, the CBO (2018) assumes that corporate taxes are not incident on households through consumer prices, but instead allocates incidence purely to owners of capital and through labor income, with three-quarters being incident on shareholders. The US Treasury model assumes an even higher incidence on shareholders, with more than four-fifths of corporate 
tax incidence borne by capital income (Cronin, Lin and Powell, 2013). Our analysis reveals a striking result: approximately half of the total incidence of corporate taxation falls on consumers through higher product prices, with capital owners bearing only $20 \%$, and workers bearing the remaining $28 \%$.

The remainder of this paper is organized as follows. Section 2 discusses our setting, presents a stylized model and our main empirical strategy. Section 3 discusses the data used for our analysis. Section 4 presents the main empirical results, and the incidence of corporate taxes on consumers. Section 5 presents placebo analyses, and explores heterogeneity in product, household and firm levels. Section 6 concludes and discusses avenues for future research.

\section{The Price Effects of Corporate Taxes}

\subsection{Mechanics of State Corporate Taxation}

State corporate tax rules vary from state to state, and typically states tax activities that occur within their own borders. ${ }^{3}$ Firms thus have tax nexus in states where they have a physical presence, such as establishments, sales, or employees. Multi-state firms must pay taxes in each state where the firm has nexus, and taxes are apportioned as a fraction of federal taxable income.

In our main empirical analysis, we take advantage of staggered changes in state level corporate tax rates, mirroring variation employed by Heider and Ljungqvist (2015). We exclude products sold in the same state where they are produced, and our empirical strategy relies on comparing how the price of items sold in one state is affected by tax changes in other states where an item is produced. Our main specifications utilize an apportionment approach to define the appropriate corporate tax rate that is incident on a producer, inclusive of both state and federal tax rates. That is, we estimate the corporate tax rates a firm is subject to given the states in which it has payroll employees and sales. Each state has different time-varying rules governing the weights applied to each of these factors. ${ }^{4}$

\footnotetext{
${ }^{3}$ See Giroud and Rauh (2019) and Heider and Ljungqvist (2015) for a detailed discussion of corporate tax nexus. The precise tax nexus also depends on whether a state has a throwback or throwout rule, under which sales of untaxed activities in other states are included in the home states' tax base.

${ }^{4}$ In the appendix, we follow Heider and Ljungqvist (2015) and Ljungqvist and Smolyansky (2016) and measure corporate taxes at the level of a firm's headquarter state, demonstrating that our results are robust to alternative definitions of the appropriate corporate tax nexus. The fact that a firm's headquarters state may not be the only state where
} 


\subsection{Model}

Our analysis begins with a stylized model demonstrating how corporate taxes impact prices, which motivates our subsequent empirical analysis. ${ }^{5}$ We assume firms operate in a standard environment similar to De Loecker (2011) and Suárez Serrato and Zidar (2016), and that firms are monopolistically competitive. Firms are endowed with some productivity level $B$, and combine labor, $L$ and capital, $K$ to produce output $y$ with the following production function, $y=B \cdot L^{\gamma} \cdot K^{1-\gamma}$.

Firms take input prices as given and the output price $p$ is given by an inverse demand curve from CES preferences with $y=I \cdot\left(\frac{p}{\bar{p}}\right)^{\varepsilon}$, where $\bar{p}$ is the price level and is normalized to 1 and $\varepsilon<0$, is the demand elasticity. The firm maximizes profits, which are taxed at a rate $\tau$. The firm thus solves:

$$
\max _{L, K}(1-\tau) \cdot(p \cdot y-w \cdot L)-\rho \cdot K
$$

where $w$ is the wage rate for labor and $\rho$ is the rate of return for capital. For any given level of $\operatorname{taxes} \tau$, if we solve the above static problem, the firm's optimal price level in $\operatorname{logs}, \ln (p)$ will be given by

$$
\ln (p)=-(1-\gamma) \ln (1-\tau)+(1-\gamma) \ln (\rho)+\gamma \ln (w)+Z
$$

where $Z$ is a constant. Appendix A provides the derivation details. Equation (2) shows that product prices, $p$, depend on corporate taxes $\tau$ and motivates our use of $\ln (1-\tau)$, i.e., the net-of-tax rate. This particular functional form for the empirical analysis follows the public finance literature and makes the coefficient readily interpretable as the net-of-tax elasticity (Suárez Serrato and Zidar, 2016; Fuest, Peichl and Siegloch, 2018). ${ }^{6}$

\subsection{Empirical Approach}

To isolate causal impacts of corporate tax changes on retail prices, we include state by retailer by year fixed effects and compare retail prices of items within the same state and year and sold by the same retailer but that are subject to different state-level corporate tax rates. We thus are able to fully control for confounding factors like local demand fluctuations which can affect both local

it has nexus may introduce some measurement error in our estimates. This would likely have the effect of attenuating these results, leading us to underestimate the incidence of corporate taxes on consumers.

${ }^{5}$ Appendix A provides further detail regarding the model.

${ }^{6}$ Our results lead to similar conclusions if we use $\ln (1-\tau)$ or $\tau$ as the primary independent variable. 
retail prices as well as propensities to change corporate tax rates. The remainder of this section outlines the approach in detail.

Our empirical approach exploits the fact that a given producer generally has physical properties and payroll that are more (and differently) geographically concentrated than their sales. That is, if a firm has most of its employees and property in a state $h$, but sales spread across many states $s \in S$, then a firm's profits will be primarily subject to the corporate tax laws of state $h$. In contrast, demand for a producer's products will be primarily affected by local economic conditions in the states in which the product is sold.

Our apportionment approach means that a given firm may be affected by the corporate tax rate in several states, depending on the geographic spread of their property, payroll, and sales and the applicable weights of the various states. For our purposes, the identifying variation will come from the fact that changes in applicable state-level corporate tax rates affecting that firm will be divorced from the economic fundamentals of the states where that firm distributes its retail goods. A product $i$ is produced by a producing firm and is sold at time $t$ in state $s$ by a retailer $r$, which operates in multiple states. In addition, our empirical measure of corporate tax rates for a given firm is always inclusive of the federal rate, which does not vary across states. We estimate the following equation, which comes directly from the theoretical model presented in Section 2.2, restricting to firms that we can identify as C-corporations.

$$
\ln \left(p_{i, f, r, s, t+1}\right)=\alpha_{r, s, t+1}+\alpha_{i, r, s}+\beta \ln \left(1-\tau_{f, t}^{c}\right)+\gamma_{1} X_{i, t+1}+\gamma_{2} X_{f, t+1}+\varepsilon_{i, f, r, s, t+1}
$$

where $p_{i, f, r, s, t+1}$ is the retail price of product $i$ of firm $f$ sold by retailer $r$ in state $s$ at time $t+1$ and $\tau_{f, t}^{c}$ is the corporate tax rate relevant for firm $f$ that produces an item. For all specifications, $\tau$ represents the sum of both federal and state level taxes. The applicable corporate tax rate for a particular firm, $\tau_{f, t}^{c}$, is a sale and employee share weighted average of state corporate tax rates in states in which it operates. See Section 3.6 for more details.

We also include product specific controls $X_{i, t+1}$, as well as controls $X_{f, t+1}$ for variables in the states in which the producer's headquarters is located. These include a various state-level controls for the headquarter state, including logged forms of total and general state revenue, state GDP and 
budget balance, the unemployment insurance base wage rate and the levels of insurance rates, state unemployment rates, investment, and unemployment compensation. $\varepsilon_{i, f, r, s, t+1}$ is an error term, which we assume is conditionally orthogonal to $\ln \left(1-\tau_{f, t}^{c}\right)$. We cluster standard errors at the firm year and retailer levels. ${ }^{7}$

We include product by retailer by sold-state fixed effects $\alpha_{i, r, s}$ for each item identified by a UPC code. These absorb time invariant product-specific price factors. Note that since each item is produced by one firm, these fixed effects also absorb the time invariant effects of the locations and networks of their producers. For example, the fixed effects capture the fact that some producers may be located in states with better transportation networks, which could lower product prices.

An important feature of our strategy is the fact that we include retailer by sold-state by year fixed effects $\alpha_{r, s, t+1}$. These fixed effects absorb any time specific factors in the seller state such as the effects of local business cycles, changing tastes in different regions, or the differential severity of recessions in particular states. These retailer by time fixed effects also capture time-specific retailer shocks, such as a major national chain declining in popularity or facing a financial shock.

Our empirical specification thus compares items sold by the same retailer in the same state at the same time, but whose producer companies face different levels of corporate taxation due to their properties and employees being mostly located in different states. In general, products in a retailer that are produced by affected out-of-state producers make up only a small fraction of total goods sold in that retailer. Thus, any change in the price of an out-of-state good affected by a corporate tax increase will likely have minimal impacts on the other goods sold in that retailer. For instance, a retail store in Nevada has only a few items sold by producers in Tennessee who are affected by a corporate tax change in Tennessee.

\section{Data}

Table 1 shows summary statistics for the main analysis variables. Appendix Tables A.1 and A.2 describe the main analysis variables and show the steps taken to link the various datasets and construct our final sample.

\footnotetext{
${ }^{7}$ In Appendix Tables A.7 and A.8, we present additional results that cluster by solely retailer or state, respectively.
} 


\subsection{State Corporate Tax Data}

To assemble data on state-level corporate tax records, we utilize and extend data shared by Giroud and Rauh (2019). In their paper, they construct a database of corporate taxes primarily from the University of Michigan Tax Database (1977-2002), the Tax Foundation (2000-2011), and the "state finance" chapter of the "Book of States." We extend this data from 2013 to 2017 utilizing the same sources, primarily relying on the Tax Foundation. To complement our analysis of C-corporations and corporate tax rates, we obtain personal income tax rate data from the NBER database for placebo tests. We drop companies headquartered in states that tax corporations in different ways, most notably a tax on gross receipts that is not comparable to a rate based on corporate income tax. For example, Ohio began to phase out its corporate franchise tax in 2005 and implemented a Commercial Activities Tax at a rate of 0.26 percent on taxable receipts exceeding one million dollars (Giroud and Rauh, 2019).

Figure 1 displays the geographic distribution of changes in corporate tax rates that we rely on for variation during our sample period. We see a substantial number of both increases and decreases in tax rates. A sizable number of these changes in corporate tax rates are fairly large, with 23 of the tax changes being $1 \%$ or more. $^{8}$

\subsection{Nielsen Retail Measurement Services (RMS) Scanner Data}

The Nielsen Retail Measurement Services (RMS) scanner data set is provided by the Kilts-Nielsen Data Center at the University of Chicago Booth School of Business. The RMS data is generated by point-of-sale systems and our sample contains over 40,000 distinct stores from 91 retail chains across 371 MSAs and about 2,500 counties between 2006 and 2017.

A distinctive feature of this database is that it provides extensive coverage of the universe of products and the full portfolio of firms within the grocery, drug, mass merchandiser, and miscellaneous retail space. The data span over 2 million unique UPC codes within 1,100 product categories. The data set comprises around 12 billion transactions per year worth, on average, $\$ 220$

\footnotetext{
${ }^{8}$ Figure A.1 displays changes in the level of corporate tax rates at three points during our sample period. Figure A.2 shows the distribution of state-level corporate tax rate levels near the two ends of our sample period and Figure A.3 illustrates the distribution of changes during our sample period. Finally, Figure A.4 displays the distribution of state-level tax revenue derived from corporate taxes across states in 2010. States generally obtain approximately $5 \%$ of tax revenue from corporate income taxes, with these taxes being a smaller source of revenue in most states than personal income taxes and sales taxes.
} 
billion. Over the sample period, the total sales observed across all retail establishments are worth approximately $\$ 2$ trillion and represent roughly half of all national sales in grocery stores or in drug stores, about a third in mass merchandisers (Argente, Lee and Moreira, 2018), including own-store brands. On a household basis, these categories of retail spending make up around $5-10 \%$ of total household expenditures in a year.

In comparison to other scanner data sets collected at the store level such as IRI Symphony dataset, the RMS covers a much wider range of products and stores. We utilize the RMS scanner data to construct a database of prices at the annual retailer-state-UPC level. For each good, we construct an annual price from the weighted average (based on the number of units sold at each price) of all goods purchased in a year. Given the large sample size, we fend off outliers in the data by dropping observations with prices above 3 times or below one-third of the product module median for each UPC in a given year, following the approach of Redding and Weinstein (2020) and Ehrlich et al. (2021). After merging with tax and firm data, the final C-corporation sample accounts for about $11 \%$ of UPCs and $17 \%$ of aggregate sales in the RMS database. ${ }^{9}$

\subsection{GS1 Barcode Data}

The GS1 Company data allows us to derive UPC level linkages between items and their producers (Argente, Lee and Moreira, 2018), giving a relatively comprehensive match for retail-goodproducing firms. The GS1 Company offers a method to map UPCs to products and individual producers in order to help firms manage their inventory. Each UPC acts as a unique identifier for a product (e.g., an individual 20-ounce plastic bottle of Coca-Cola Classic) and allows us to link purchase and price in the RMS data to information about the firm that produced each item, as well as the location of a given firm's headquarters. UPCs (barcodes) are nearly ubiquitous for products carried by the retailers that we study and, if they are in a relevant industry, will be available for essentially all goods that a given producer manufactures. Moreover, the linkages should be unique

\footnotetext{
${ }^{9}$ In the appendix, we show that the results are robust to using the Nielsen Homescan dataset. This dataset is more restricted than the RMS, as it collects information on the realized purchases of 40,000-60,000 US households and covers less than $60 \%$ of the products the RMS covers in a given year. However, the Homescan panel is constructed as a representative sample of the American population and is tracked through the inclusion of numerous demographic indicators, including the location of the household. For each of these households, the Homescan panel covers approximately $\$ 400$ of spending per month (about $\$ 5,000$ per year). We report results using the Homescan data mirroring our main results in Appendix Table A.4.
} 
for a product and are generally unchanged over time.

The link between UPC code and producer is driven by the first 6 to 9 digits of the UPC, known as the 'company prefix.' However, the number of digits contained in this company prefix is not fixed across UPCs and firms. Thus, for each UPC, we extract its first 6 to 9 digits as four company prefix candidates. Then we match these candidates to the pool of company prefixes in order to create possible UPC-producer links. According to the GS1, "As the GS1 Company Prefix varies in length, the issuance of a GS1 Company Prefix excludes all longer strings that start with the same digits from being issued as GS1 Company Prefixes." Essentially, for one particular UPC code with its associated four company prefix candidates, there will be only one candidate fully matched to the company prefix pool. Our matching algorithm confirms this unique relationship. In the end, we use the GS1 Data Hub to exactly match $83 \%$ of the UPCs in the data to a GS1 company prefix.

\subsection{Orbis Data - Firm Location and Structure}

We construct our database on firm characteristics primarily through the use of the Orbis database, developed by Bureau van Dijk (BvD). This database contains administrative and ownership data on 130 million firms across the globe. It covers both public and private firms, offering us an opportunity to identify the incorporation type of producers in our pricing database.

Orbis collects data on both public and private firms from administrative and other sources and organizes them in a consistent format. This includes information on the legal form/incorporation type that a given firm has undertaken, as noted by the 'Standardized Legal Form' and 'National Legal Form' variables. Unfortunately, these variables do not definitively determine whether a firm is a C-corporation or an S-corporation and we are forced to also supplement these variables with information on the number and type of shareholders in order to infer the incorporation type.

We first utilize the legal forms to categorize all public companies as $\mathrm{C}$-corporations. We treat partnerships as S-corporations and non-profit organizations and public authorities as firms that are exempt from corporate taxes altogether. For the rest of the unidentified producers, we resort to information about their shareholders. We download the legal form information and the shareholder information of firms at the most recently available date. There is a reporting lag in Orbis data of roughly two years. Since we downloaded the data in 2019, the latest available year is 2017 or occasionally 2016. 
According to the definition of S-corporations (26 U.S. Code 1361.(b)), they should not have more than 100 shareholders and their shareholders should be individuals, not other firms or holding companies. Consequently, we treat producers who have more than 100 shareholders or who have non-individual shareholders as C-corporations, i.e., firms ineligible to be taxed as S-corporations. Due to data limitations, what we identify is essentially whether a firm is eligible to elect to be taxed as an S-corporation. However, whether the eligible firms execute this option is unobserved to us.

For those firms that satisfy the shareholder requirement, they can still elect to be taxed as a Ccorporation, rather than choose to pass the income to their shareholders. Therefore, this approach enables us to relatively accurately measure C-corporations, while S-corporations could only be more noisily identified. For this reason, we use accurately identified C-corporations for baseline analysis and use the noisily identified S-corporations to conduct placebo tests in similar spirit to Giroud and Rauh (2019) and Yagan (2015).

To match our categorized Orbis data to our database of prices, we make use of matching software on the web platform of Orbis. This system automatically matches firms according to names, locations, industry and other information. Since firms could operate in multiple locations, we restrict the matching criteria to company names and industries. We also conduct hand-matching on firm names to supplement the matching for the largest firms in our sample. In the end, we match approximately $80 \%$ GS1 producers and over $90 \%$ of all the UPCs in our pricing data.

\subsection{Reference USA (Infogroup) Data}

Broadly, Infogroup provides data on tens of millions of businesses in the United States at both aggregated and disaggregated levels. These data are collected by Infogroup in a variety of ways, including utilizing public statistics as well as detailed follow-ups such as direct phone calls and emails to businesses. ${ }^{10}$

In particular, we use data from Reference USA (owned by Infogroup) to establish the geographic spread of business activity within a given firm, as measured by the location of employees in a firm across states. Because of known issues with the categorization of establishments within a

\footnotetext{
${ }^{10}$ Because of the manpower-intensive requirements for data collection in this manner, employment data from year to year is sometimes held over for a given establishment. However, we note that most of the variation we exploit is designed to reflect geographic dispersion across firms rather than changes within-firm over time, so this source of error is likely not greatly impacting our analysis.
} 
firm (e.g., mis-measuring a retail establishment as a pharmacy), we utilize all establishments from a given firm and do not restrict to a particular category of establishment. We use this geographic distribution of employees and sales to compute the weighted average tax rate for a firm. Because Infogroup does not track the distribution of property or capital across establishments, we assume that property and plant are distributed in the same way as employment.

\subsection{State Tax Apportionment}

Each state that levies a corporate tax uses a formula to determine the fraction of a firm's activities that occurred in that state for tax purposes. In general, states attempt to measure this concept using a weighted average of the fraction of sales, property, and employees a firm has in that state. These apportionment weights vary significantly across states and over time. Thus, the actual corporate tax rate that a firm is subject to is itself a weighted average of these state-level tax rates. For firms operating in many states, they may be affected by changes in corporate tax rates in any one of those states, but will be most heavily affected by corporate tax rates in the state in which they have a majority of their operations.

We approximate the effective tax rate according to the geographic distribution of sales, property and employment following state apportionment rules. We match the producers from the GS 1 database to the Reference USA dataset, which tracks firms' sales and employment at the establishment level. This allows us to compute a firm's nexus-based tax rate as follows:

$$
\tau_{f, t}^{c}=\sum_{s}\left(\omega_{s, t}^{e m p} \frac{E_{f, s, 0}}{E_{f, t o t a l, 0}}+\omega_{s, t}^{\text {sales }} \frac{S_{f, s, 0}}{S_{f, t o t a l, 0}}+\omega_{s, t}^{\text {prop }} \frac{P_{f, s, 0}}{P_{f, t o t a l, 0}}\right) \times \tau_{s, t}^{c}
$$

where the $\tau_{f, t}^{c}$ is the nexus-based corporate tax rate for firm $f$ in year $t$. We construct this using $E_{f, s, 0}, S_{f, s, 0}$ and $P_{f, s, 0}$ which are firm $f$ 's number of employees, sales and property values in state $s$ in the first year 0 we observe the firm, while $E_{f, t o t a l, 0}, S_{f, t o t a l, 0}$ and $P_{f, t o t a l, 0}$ are the total number of employees, sales and property values across all states of firm $f$ in year $0 .{ }^{11}$ Year 0 represents the first year we observe the firm in our sample to avoid endogenous changes in business activity based on corporate tax changes. $\omega_{s, t}^{e m p}, \omega_{s, t}^{\text {sales }}$ and $\omega_{s, t}^{\text {prop }}$ are the state apportionment formulas at time $t . \tau_{s, t}^{c}$ is the state $s$ 's corporate tax rate in year $t$. For our regressions of prices on taxes, tax

\footnotetext{
${ }^{11}$ Due to data limitation, we use the employee share to approximate the property value share, following Suárez Serrato and Zidar (2016).
} 
rates will be calculated as the sum of this state-driven tax rate and the overall federal corporate tax rate. We discuss this approach further in Appendix Section B.

In addition to the state-level corporate tax rates, we extract apportionment rates and throwback or throw-out rules from the Commerce Clearing House's State Tax Handbooks up through 2017. We also collect data on state investment incentive programs during 2006 and 2017 (i.e., tax credits for investment, $\mathrm{R} \& \mathrm{D}$, and job creation, as well as job creation grant programs) from three sources: individual state-level Department of Economic Development websites, Department of Revenue websites, and legislature websites. The numbers are also double-checked with State Tax Rule Books when available. ${ }^{12}$

\section{Main Results}

\subsection{Main Estimates of Tax Elasticity}

Table 2 presents estimates of equation (3), using ordinary least squares. All specifications include UPC by retailer by sold-state fixed effects, and other controls noted in Section 2.3. Column (1) includes controls and UPC by retailer by sold-state fixed effects as well as year fixed effects to control for macroeconomic conditions. The estimates suggest large changes in retail prices stemming from corporate tax changes (measured as the change in state and federal corporate tax rates), with a statistically significant elasticity of prices to net of corporate tax rates of approximately 0.32 .

To further control for state-specific economic conditions, column (2) includes sold-state by year fixed effects. These capture state-specific temporal factors, for example the housing boom and bust being more severe in certain states (for instance, Stroebel and Vavra (2019) show that local real estate prices impact retail prices). Column (3) uses retailer by year fixed effects. The retailer by year fixed effects address firm-specific temporal shocks (e.g., firm financing shocks may impact retail prices (Kim, 2018)) and decrease our estimated effects by approximately 25\%. Column (4) includes both sold-state by year and retailer by year fixed effects. Finally, column (5) adds in soldstate by retailer by year fixed effects. The results, a net-of-tax elasticity of approximately 0.24 ,

\footnotetext{
${ }^{12}$ We show in the Appendix Table A.5 that the results are also robust to utilizing a different measure of tax nexus, based on a firm's headquarter location only. The point estimates are slightly smaller in terms of absolute value, which is consistent with a firm's headquarter location being a noisy proxy for the true tax nexus. The number of observations is also smaller than the baseline table as we drop firms headquartered in states that do not levy corporate income taxes.
} 
again remain very similar to those in column (4).

Figure 2 shows the timing of price effects following large tax changes. This exercise serves as a test of our identification strategy, and the timing of observed results should coincide with the timing of tax changes. We define a large tax event as an increase or decrease of more than one percentage point for a firm, following Giroud and Rauh (2019).

We re-estimate our main specification, replacing the main treatment with an indicator of a time period before and after the large tax event, scaled by the change of tax rate. ${ }^{13}$ The shaded area denotes a 95\% confidence interval. We indeed find that the timing of observed effects lines up with large tax changes. That is, we see insignificant effects in the years prior to the tax event but substantial price effects following the tax change.

\subsection{Plausibility Check on Magnitudes}

In the previous section, we utilize a reduced form estimation to measure the elasticity of prices to corporate taxes. However, one should not interpret our estimates as $1-\gamma$, the capital share of gross output. Tax increases have a direct effect on wages, which we do not observe, so we cannot separately identify the effect of taxes on wages. ${ }^{14}$ In fact, our empirically identified price elasticity $I_{p}$ will be equal to $1-\gamma-\gamma I_{w}$ in absolute value, where $I_{w}$ is the wage elasticity. ${ }^{15}$

With a value of $\gamma$ of 0.58 (Chetty et al., 2011), we can utilize our empirical estimate of $I_{p}$ to back out $I_{w}=0.3$, matching the estimate the corporate income tax elasticity of wages of $0.3-0.4$ in Germany from Fuest, Peichl and Siegloch (2018). We take this back-of-envelope calculation as evidence that our estimate for the price elasticity to corporate taxes is of reasonable magnitude.

We can also extend the model in section 2.2 to include intermediate goods in the production function and use the model as well as estimates from the literature to separately identify the intermediate input good price elasticity. Ex ante, this should be weakly lower than the product price

\footnotetext{
${ }^{13}$ Specifically, the figure plots coefficients $\beta_{n}$ from the following specification: $\ln \left(p_{i, f, r, s, t}\right)=\alpha_{r, s, t}+\alpha_{i, r, s}+$ $\sum_{n=-3}^{n=4} \beta_{n} \mathbb{1}[t=n] \times \Delta \ln \left(1-\tau_{f, t}^{c}\right)+\gamma_{1} X_{i, t}+\gamma_{2} X_{f, t}+\varepsilon_{i, f, r, s, t}$.

${ }^{14}$ Indeed wages could directly affect product prices as shown in Equation 2. However, to the extent that changes in wages are due to changes in corporate taxes, the effect on prices is already captured by our empirical strategy through the $\log$-linear term of $\ln (1-\tau)$. In unreported analyses, we further control for higher-order terms of $\tau$ to allow for potential non-linear effects of corporate taxes on wages, and find results unchanged. It is also worth noting that, since an increase in corporate taxes leads to lower wages and wages and product prices are positively correlated, this at best introduces a non-first-order underestimate bias into our empirical estimate.

${ }^{15}$ We assume capital owners supply capital perfectly elastically at the national rate, consistent with Suárez Serrato and Zidar (2016).
} 
elasticity, as intermediate goods may be sourced in the same state a firm is located, or another state. ${ }^{16}$ Our data cannot separately identify wage or intermediate input price change. Therefore our identified price incidence includes wage incidence, which we denote $I_{w}$, and intermediate good price incidence is denoted by $I_{M}$. Our empirically identified price incidence $I_{p}$ will be equal to $-\delta+\gamma I_{w}+(1-\delta-\gamma) I_{M}$

We follow Suárez Serrato and Zidar (2016) and can set the values of $\gamma$ (the labor elasticity) and $1-\gamma-\delta$ (where $\delta$ is the capital elasticity) accordingly using BEA's 2012 data on shares of gross output by industry. These indicate that for private industries, compensation and intermediate inputs account for $28.5 \%$ and $45.6 \%$ respectively of the shares of gross output. Given our estimate of $I_{p}=-0.24$ and implied $I_{w}=0.3$, the back-of-envelope calculated intermediate good price elasticity $I_{M}=-0.16$. As firms' intermediate inputs could be sourced locally or nationally, this estimate is a reasonable value of intermediate price incidence compared with the output price elasticity of -0.24 .

\subsection{Incidence of Corporate Taxes on Consumers}

Our empirical analysis estimates the elasticity of the output price with respect to the net-of-business tax rate, $\delta_{p}=\frac{d p}{d(1-\tau)} \frac{(1-\tau)}{p}$. Armed with this estimate, we quantify the incidence of corporate taxes on product prices as the share of the total corporate income tax burden borne by consumers. We enrich the setting in Fuest, Peichl and Siegloch (2018) by allowing for the welfare change of consumers induced by a marginal change in the net-of-tax rate, alongside workers and firm owners.

More specifically, we consider three types of agents: (1) the consumer in state $s$ and (2) the worker and (3) the firm owner, both in state $h$. We assume that $h \neq s$, which is consistent with our empirical setting. Consumers maximize the utility function $U\left(C_{s}, L_{s}\right)$ given the budget constraint: $p \cdot C_{s}=\left(1-\tau_{s}^{p}\right) w_{s} L_{s}$, where $p$ is the price for the consumption good, $C_{s}$ is consumption quantity, $\tau_{s}^{p}$ is personal income tax rate, $w_{s}$ is the wage received by consumer and $L_{s}$ is the quantity of labor. Since the consumer we are concerned with is not from the state where there is a tax shock, we assume the wage and labor supply, $w_{s}$ and $L_{s}$, will not change. We can write the indirect utility function as $V_{\text {cons }_{s}}(p)$ and a change in consumer utility as a result of a change in the product price is

\footnotetext{
${ }^{16}$ In the extreme case where all intermediate goods are sourced out of states that do not witness any tax change, the intermediate good price elasticity could be 0 .
} 
given by $d V_{\text {cons }_{s}}=-C_{s} \cdot d p$, by the envelope theorem.

The worker in state $h$ will maximize the utility function $U\left(C_{h}, L_{h}\right)$ given the budget constraint: $p \cdot C_{h}=\left(1-\tau_{h}^{p}\right) w_{h} L_{h}$, where for simplicity we assume only wages are affected. Then the indirect utility is given by $V((1-\tau) w)$ and the change in worker utility induced by tax change is $d V_{w k r_{h}}=\left(1-\tau_{h}^{p}\right) L_{h} \cdot d w_{h}$. A representative firm in state $h$ faces a corporate tax rate $\tau_{h}^{c}$ and maximizes profits, $\Pi=\left(1-\tau_{h}^{c}\right)\left(p F\left(K, L_{h}\right)-w_{h} L_{h}\right)-r K$, over capital $K$ and labor $L$. We similarly apply the envelope theorem and solve for the marginal effect in welfare for firm owners: $d V_{f_{h}}=\left(1-\tau_{h}^{c}\right) F\left(K, L_{h}\right) d p-\left(p F\left(K, L_{h}\right)-w_{h} L_{h}\right) d \tau-\left(1-\tau_{h}^{c}\right) L_{h} d w_{h}$.

The share of consumers, workers and firm owners in the overall burden of a marginal change in the corporate tax rate is given by the respective share of their own marginal effect in welfare out of the total sum $d V_{\text {con }_{s}}+d V_{f_{h}}+d V_{w r k_{h}}$. For example, the share of the tax burden borne by consumers is $I_{\text {con }}=\frac{d V_{\text {cons }}}{d V_{\text {cons }}+d V_{f_{h}}+d V_{\text {wrkh }}}$. The share of consumers in the tax burden can be expressed as:

$$
I_{\text {con }_{s}}=\frac{s_{\text {con }} \delta_{p}}{s_{\text {con }} \delta_{p}-\left(\tau_{h}^{c}-\tau_{h}^{p}\right) s_{\text {labor }} \delta_{w}-\left(1-\tau_{h}^{c}\right) \delta_{p}-\left(1-\tau_{h}^{c}\right)\left(1-s_{\text {labor }}\right)}
$$

Here, $s_{c o n}=\frac{p C_{s}}{p F\left(K, L_{h}\right)}$ is the consumption share over total output and $s_{\text {labor }}=\frac{w_{h} L_{h}}{p F\left(K, L_{h}\right)}$ is the labor share over total output. $\delta_{p}$ is the tax elasticity of price and $\delta_{w}$ is the tax elasticity of wage. The price elasticity and wage elasticity to the net of tax rate are two sufficient statistics to calculate marginal welfare changes of consumers, workers and firms. ${ }^{17}$

Our data allows for identification of the output price elasticity, which we find to be $\delta_{p}=-0.24$ and the implied wage elasticity so that $\delta_{w}=0.3$. Using this, we can calculate that the incidence on consumers, workers and shareholders is $52 \%, 28 \%$, and $20 \%$, respectively. Alternatively, using the estimate from Table 6 (including additional controls) or Table A.4, $\delta_{p}=-0.20$, the tax incidence on consumers, workers and firm owners are $43 \%, 36 \%$, and $21 \%$, respectively. In contrast, if we do not take into account the effect of corporate income tax on product prices, the resultant incidence falls primarily (70\%) on capital. This is consistent with Suárez Serrato and Zidar (2016) - as they find that the incidence of the corporate tax falls $65-70 \%$ on capital - as well as with CBO and Treasury estimates. The results suggest that close to half of corporate tax incidence falls on

\footnotetext{
${ }^{17} \mathrm{We}$ also use $s_{\text {con }}=0.675$ from BEA's consumption share of GDP, $s_{\text {labor }}=0.5$ from the sector-level estimate of Giandrea and Sprague (2017), $\tau_{h}^{p}=0.40$ as personal income tax rate including federal and state taxes, and $\tau_{h}^{c}=$ 0.42 as the sum of federal $35 \%$ and state level average $7 \%$ corporate income tax rate. Appendix A provides further derivation details.
} 
consumers, potentially making corporate taxes more similar to sales taxes and hence much less progressive.

\subsection{State Level CPI and Corporate Taxes}

While the Nielsen data are able to leverage detailed product and producer level data to investigate the linkage between corporate taxes and prices, they are limited in the scope of products and services that they cover. The Nielsen retail data are naturally limited to a subset of retail spending, comprising only a moderate fraction of total consumer spending in the economy. Thus, our consumer incidence calculations make the extrapolation of price effects extending to other products and sectors that are not covered by Nielsen - for example restaurant spending, large durables, residential costs, and medical expenses.

To provide some additional evidence that corporate taxes may have impacts on prices more broadly, we conduct a similar exercise at a wider scale. In Table 3, we combine state level inflation data with our state corporate tax data. In general, we find that state-level consumer prices tend to rise more quickly in states seeing increases in corporate taxes.

Column 1 shows a bivariate regression between the logged net of tax rate against state-level inflation. In columns 2-4, we add in state and year fixed effects along with economic controls (statelevel unemployment and a economic conditions coincident indicator developed by the Philadelphia Federal Reserve) to control for time-varying state-level economic cycles. These aggregate results are economically and statistically different than zero, providing further evidence that assumptions of zero pass-through from corporate taxes to prices may need revision.

We find a strong negative relationship between the two, suggesting higher consumer prices occur alongside higher corporate taxes. Coefficients are substantially below those we estimate in our detailed consumer products regressions, though this may be expected given the substantial share of purchases that make up CPI inflation which are less subject to corporate tax incidence (e.g., housing). These results are not as precisely identified as those in our main analysis owing to their aggregated nature and inability to fully control for local business cycles, but they suggest that other sectors of the economy may see impacts of corporate taxes on prices. We encourage further work to provide additional well identified estimates of the economy-wide impacts of corporate taxes to better understand the aggregate and general equilibrium impacts of corporate taxes in this 
area.

\section{Placebo Analysis and Heterogeneity}

\subsection{Placebo Analysis: S- and C- Corporations}

So far, we have focused on C-corporations, which are subject to corporate income taxation. A natural placebo test is to repeat our analysis on other firms that produce goods for retail sales but do not pay corporate taxes (Yagan, 2015; Giroud and Rauh, 2019). In the United States, S-corporations fill this role as they are subject to personal income tax rates on their earnings. Figure 3 shows binscatters of annual price changes and tax changes for both C-corporations and Scorporations. The left panel shows the relationship for C-corporations and the right panel displays the same relationship for S-corporations.

While all firms that we classify as C-corporations will be properly classified, there is some classification error for S-corporations. This is discussed in more detail in Section 3.4, and will result in classifying some C-corporations as S-corporations. This measurement error would likely bias us away from finding a zero result for firms classified as S-corporations. In this Figure, we find a strong negative relationship between changes in corporate taxes and prices for C-corporations, consistent with the evidence presented in Table 2. However, we see an upward sloping and statistically insignificant relationship between changes in prices and changes in corporate tax rates for S-corporations. The fact that we see no impact of tax changes on firms that do not pay corporate taxes suggests that any possible source of bias in our estimates must impact only C-corporations, but not S-corporations. This relationship is tested and confirmed in a regression framework in Table 4, where we include the full battery of fixed effects as in our main specifications.

Another version of our placebo test can be conducted by replacing the corporate income tax rate with personal income tax rate in equation (3). That is, we test whether the prices of C-Corporationproduced retail goods are responsive to personal income tax rates. We present our results in Table 5. The coefficients are very close to zero in magnitude and not statistically significantly different from zero, confirming that the changes in state-level corporate income tax rates are not capturing other time-varying shocks that coincide with changes in product prices. 


\subsection{Additional State Controls and Robustness}

While our state by year fixed effects rule out any time varying sold-state specific demand channel, they do not capture time varying producer state factors that could be correlated with corporate tax changes. One potential concern is that corporate tax increases or cuts may be coupled with corresponding changes in state policies that could impact firms. For example, states may couple increases in corporate tax rates with increases in $\mathrm{R} \& \mathrm{D}$ tax credits or job creation tax credits. We note that our placebo tests using S-corporations suggest this is not the case, as S-corporations are not similarly affected as C-corporations. Here we conduct an additional test, adding additional controls for producer state policy changes.

Table 6 explores this concern, by adding the following producer state controls used in Heider and Ljungqvist (2015): (1) investment tax credits (2) upper and lower bounds of R\&D tax credits (3) job creation tax credit indicators and (4) job creation grant indicators. ${ }^{18}$ The elasticity estimates remain statistically significant, suggesting that the effects are not driven by observable producer state policy changes that coincide with corporate tax changes.

In the appendix we also show that our results are robust to a number of alternative specifications. We show in Appendix Table A.6 that our results are robust to the inclusion of other fixed effects variants. As mentioned previously, in Appendix Table A.5 we also demonstrate that our results are robust to using an alternative measure of corporate taxes, the state headquarter tax rate, as in Heider and Ljungqvist (2015).

\subsection{Heterogeneity by Price and Household Income}

We also examine several dimensions along which passthrough of corporate tax changes to retail prices varies across firms or products with different characteristics. First, Table 7 examines how the effect of corporate taxes on retail prices differs across individual products. We break down the UPCs in our sample according to the average income of the households who typically purchase that item. The Nielsen Consumer Panel data tracks household income according to income bins that vary at an annual level and range from $\$ 5,000$ to $\$ 200,000$. We use the midpoints of these bins

\footnotetext{
${ }^{18}$ The data on state investment incentive programs are primarily collected from three sources. First, state Department of Economic Development websites, second, Department of Revenue websites and finally state legislature websites. When possible, we double-check estimates with State Tax Rule Books.
} 
and construct the weighted average of household income for the average customer for each UPC.

In general, we find larger effects for UPCs commonly purchased by households with higher incomes relative to those purchased by low-income households. The point estimates are substantial, with pass-through of corporate tax changes approximately $30 \%$ greater for products with average purchaser income at the 75th percentile relative to the median (reflecting a median logged income of approximately 11.06 and a 75th percentile income of 11.13).

In Panel B, we look for differential responses across UPCs depending on how expensive the products are, on average. That is, for each UPC we measure the average price paid by households across all time periods in our sample. We find that the lower priced goods tend to respond less to corporate tax changes. The average passthrough to prices of a product at the 75 th percentile is approximately $60 \%$ larger than that for the median price. This difference is also statistically significant, suggesting a robust pattern of higher pass-through for higher-priced goods.

\subsection{Heterogeneity in Competition}

We investigate the heterogeneity of the pass-through regarding the market competition. To measure the level of market competition, we calculate the HHI index for each product market, using the product group information in the Retailscan data. Retailscan offers detailed categorization of each product across 125 product groups stored in the Nielsen RMS data. Examples of product group are beer, coffee, eggs, packaged meat, or candy. We define each product group as a separate market and calculate the HHI for each of them in different years. We first aggregate a company's sales in one market in one year and then estimate the market share. By summing up the square of market shares, we obtain the HHI for the market in each year. Given the national representativeness of the RMS, the market share should be a good approximation of the real market share.

It is possible for the product group of a UPC to change within one year, and since we aggregate the product prices within one year into one observation, it is not obvious to assign a product market to the yearly observation if the product group changes. Therefore, based on our main sample, we further restrict to UPCs that don't change their categorization within one year (a restriction affecting less than $1 \%$ of the sample). Across all product groups, the median HHI is 0.10 and the mean and standard deviations are 0.15 .

Table 8 interacts corporate tax rates with the Herfindahl-Hirschman Index (HHI) of the product 
group in a given year. The results suggest lower pass-through in more competitive markets and are consistent with theories in which competitive markets prevent firms from passing through increased costs. Overall, we find that a one standard deviation change in product group HHI $(0.15)$ is associated with an increase in price elasticity of 0.075 . Relative to a baseline estimate of 0.24 , this represents a $31 \%$ increase in price elasticity. ${ }^{19}$

Our finding that the level of product group competition has a negative relationship with the tax passthrough resonates with findings in the tax incidence literature for sales and excise taxes. In a perfectly competitive market, sales and excise taxes could be fully shifted onto consumers; under imperfect competition, over-shifting is possible (Bishop, 1968; Stern, 1987; Delipalla and Keen, 1992). Empirical studies of the effects of sales and excise taxes on prices such as Poterba (1996) and Besley and Rosen (1999) find evidence of over-shifting and interpret them as indicating that certain markets are operating under imperfect competition. Our result also echoes the finding in Jacob, Müller and Wulff (2022), who use German data and find gas stations facing less elastic consumers pass on more of the business tax to consumers.

It is worth noting that our context is a partial equilibrium situation where a subset of firms competing in a market is subject to corporate tax changes, rather than the case that a tax change is applied uniformly to all firms competing in a market, as typically for sales or excise taxes. Given this partial equilibrium setting, when considering the effect of imperfect competition, the level of tax passthrough depends on the relative elasticity of the demand and supply (Fullerton and Metcalf, 2002). That is, how easily consumers can substitute the products of affected firms by other firms will affect the magnitude of the tax passthrough. A more concentrated product market will therefore indicate a more inelastic demand curve, which allows for a higher tax passthrough to consumers (Lockwood, 1990).

\footnotetext{
${ }^{19} \mathrm{We}$ also perform test of heterogeneous passthrough based on debt holdings and effects on product offerings. Appendix Table A.9 examines differential impacts of corporate debt on passthrough of corporate taxes. We merge our sample to Compustat to obtain information on leverage. Overall, we find no strong evidence for differential rates of passthrough to retail prices along this margin. In Appendix Table A.10, we note that increases in corporate tax rates tend to also reduce the number of products offered by a given producer.
} 


\section{Concluding Remarks}

This paper provides evidence that corporate taxes impact retail product prices, and that a significant portion of corporate tax incidence falls on consumers. We link firm-level data to individual product prices and to changes in a firm's apportioned tax rates to examine their effects on retail prices. A one percentage point increase in a state-level corporate tax rate leads to an increase in affected retail prices of approximately 0.24 percent. Our analysis exploits state-level tax changes, and the fact that goods produced in a firm located in one state are sold in another state. This allows us to include sold-state by retailer by year fixed effects, thus avoiding a large number of potential biases and demand-side concerns.

The fact that corporate taxes affect product prices, as well as payouts to shareholders and wages, has important implications for tax policy. In particular, models used by policymakers like the CBO and US Treasury may underestimate the incidence of corporate taxes on consumers (CBO, 2018; Cronin et al., 2013). If corporate taxes are partially incident on consumers, rather than primarily being borne by shareholders and workers, these taxes may be much less progressive than is commonly asserted.

There remain several fruitful avenues for further exploration. First, our analysis necessarily focuses on trade across US states, which are essentially small open economies. Much of the early theoretical debate on corporate tax incidence focused on differences between open and closed economies. Effects may be different at the national level, where there are different opportunities for tax avoidance or adjustments in corporate structure. Second, market structure could play an important role in price pass-through of taxes. While we conduct some exploratory tests in this paper, more in-depth analysis is warranted. Third, we focus on retail goods due to the availability of high quality pricing data, incidence may be very different in other sectors or in services. 


\section{References}

Akcigit, Ufuk and Stefanie Stantcheva, “Taxation and innovation: What do we know?, Technical Report, National Bureau of Economic Research 2020.

_, John Grigsby, Tom Nicholas, and Stefanie Stantcheva, "Taxation and innovation in the twentieth century," The Quarterly Journal of Economics, 2022, 137 (1), 329-385.

Argente, David, Munseob Lee, and Sara Moreira, "Innovation and product reallocation in the great recession," Journal of Monetary Economics, 2018, 93, 1-20.

Auerbach, Alan, "Who bears the corporate tax? A review of what we know.," Tax Policy and the Economy, 2006, 20, 1-40.

Bertrand, Marianne and Sendhil Mullainathan, "Enjoying the quiet life? Corporate governance and managerial preferences," Journal of Political Economy, 2003, 111 (5), 1043-1075.

Besley, Timothy J and Harvey S Rosen, "Sales taxes and prices: an empirical analysis," National tax journal, 1999, 52 (2), 157-178.

Bishop, Robert L, "The effects of specific and ad valorem taxes," The Quarterly Journal of Economics, 1968, 82 (2), 198-218.

Broda, Christian and David E. Weinstein, "Product creation and destruction: Evidence and price implications," American Economic Review, 2010, 100 (3), 691-723.

CBO, "The distribution of household income, 2014," Congressional Budget Office Staff Report, 2018.

Chetty, Raj, Adam Guren, Day Manoli, and Weber Andrea, "Are Micro and Macro Labor Supply Elasticities Consistent? A Review of Evidence on the Intensive and Extensive Margins," American Economic Review: Papers and Proceedings, 2011.

Cronin, Julie Anne, Emily Lin, and Laura Powell, "Distributing the corporate income tax: Revised U.S. Treasury methodology," National Tax Journal, 2013, 66 (1), 239-262.

Dedola, Luca, Chiara Osbat, and Timo Reinelt, “Tax thy neighbour: Corporate tax pass-through into downstream consumer prices in a monetary union," Working Paper, 2022.

Delipalla, Sofia and Michael Keen, "The comparison between ad valorem and specific taxation under imperfect competition," Journal of Public Economics, 1992, 49 (3), 351-367. 
Ehrlich, Gabriel, John Haltiwanger, Ron Jarmin, David Johnson, Ed Olivares, Luke Pardue, Matthew D Shapiro, and Laura Yi Zhao, "Quality adjustment at scale: Hedonic vs. Exact demand-based price indices," Working Paper, 2021.

Einav, Liran, Ephraim Leibtag, and Aviv Nevo, "Recording discrepancies in Nielsen Homescan Data: Are they present and do they matter?," Quantitative Marketing and Economics, 2010, 8 (2), 207-239.

Fajgelbaum, Pablo D, Eduardo Morales, Juan Carlos Suárez Serrato, and Owen Zidar, "State taxes and spatial misallocation," The Review of Economic Studies, 2018, 86 (1), 333376.

Feldstein, Martin and Joel Slemrod, "Personal taxation, portfolio choice and the effect of the corporation income tax," Journal of Political Economy, 1980, 88 (5), 854-866.

Fuest, Clemens, Andreas Peichl, and Sebastian Siegloch, "Do higher corporate taxes reduce wages? Micro evidence from Germany," American Economic Review, 2018, 108 (2), 393-418.

Fullerton, Don and Gilbert E Metcalf, “Tax incidence," Handbook of Public Economics, 2002, 4, 1787-1872.

Giandrea, Michael D and Shawn A Sprague, "Estimating the US labor share," Monthly Labor Review, 2017.

Giroud, Xavier and Joshua Rauh, "State taxation and the reallocation of business activity: Evidence from establishment-level data," Journal of Political Economy, 2019, 127 (3).

Gravelle, Jane and Laurence Kotlikoff, “The incidence and efficiency costs of corporate taxation when corporate and noncorporate firms produce the same good," Journal of Political Economy, 1989, 97 (4), 749-780.

Gravelle, Jennifer, “Tax Incidence,” National Tax Journal, 2013, 66 (1), 185-214.

Harberger, Arnold, "The incidence of the corporation income tax," Journal of Political Economy, 1962, 70 (3), 215-240.

Heider, Florian and Alexander Ljungqvist, "As certain as debt and taxes: Estimating the tax sensitivity of leverage from state tax changes," Journal of Financial Economics, 2015, 118 (3), $684-712$.

Jacob, Martin, Maximilian A Müller, and Thorben Wulff, "Do consumers pay the corporate tax?," Working Paper, 2022. 
Kim, Ryan, "The effect of the credit crunch on output price dynamics: The corporate inventory and liquidity management channel," Working Paper, 2018.

Kotlikoff, Laurence and Lawrence Summers, "Tax incidence," Handbook of Public Economics, 1987, 2, 1043-92.

Krzyzaniak, M and RA Musgrave, "The shifting of the corporation income tax," Baltimore: Johns Hopkins Press, 1963.

Krzyzaniak, Marian and Richard A Musgrave, "Incidence of the corporation income tax in US manufacturing: Comment," The American Economic Review, 1968, 58 (5), 1358-1360.

Ljungqvist, Alexander and Michael Smolyansky, "To cut or not to cut? On the impact of corporate taxes on employment and income.," Working Paper, 2016.

_ , Liandong Zhang, and Luo Zuo, "Sharing risk with the government: How taxes affect corporate risk taking," Journal of Accounting Research, 2017, 55 (3), 669-707.

Lockwood, Ben, “Tax Incidence, Market Power, and Bargaining Structure," Oxford Economic Papers, 1990.

Loecker, Jan De, "Product differentiation, multiproduct firms, and estimating the impact of trade liberalization on productivity," Econometrica, 2011, 79 (5), 1407-1451.

Poterba, James M, "Retail price reactions to changes in state and local sales taxes," National Tax Journal, 1996, 49 (2), 165-176.

Redding, Stephen J and David E Weinstein, "Measuring aggregate price indices with taste shocks: Theory and evidence for CES preferences," The Quarterly Journal of Economics, 2020, $135(1), 503-560$.

Stern, Nicholas, "The effects of taxation, price control and government contracts in oligopoly and monopolistic competition," Journal of Public Economics, 1987, 32 (2), 133-158.

Stroebel, Johannes and Joseph Vavra, "House prices, local demand, and retail prices," Journal of Political Economy, 2019, 127 (3).

Suárez Serrato, Juan Carlos and Owen Zidar, "Who benefits from state corporate tax cuts? A local labor markets approach with heterogeneous firms," American Economic Review, 2016, 106 (9), 2582-2624.

Yagan, Danny, "Capital tax reform and the real economy: The effects of the 2003 dividend tax cut," American Economic Review, 2015, 105 (12), 3531-63. 
Figure 1: Change in State Corporate Taxes

Notes: This figure shows the change in state corporate tax rates between 2004 and 2017 in percentage points. Source: Giroud and Rauh (2019) and Tax Foundation.

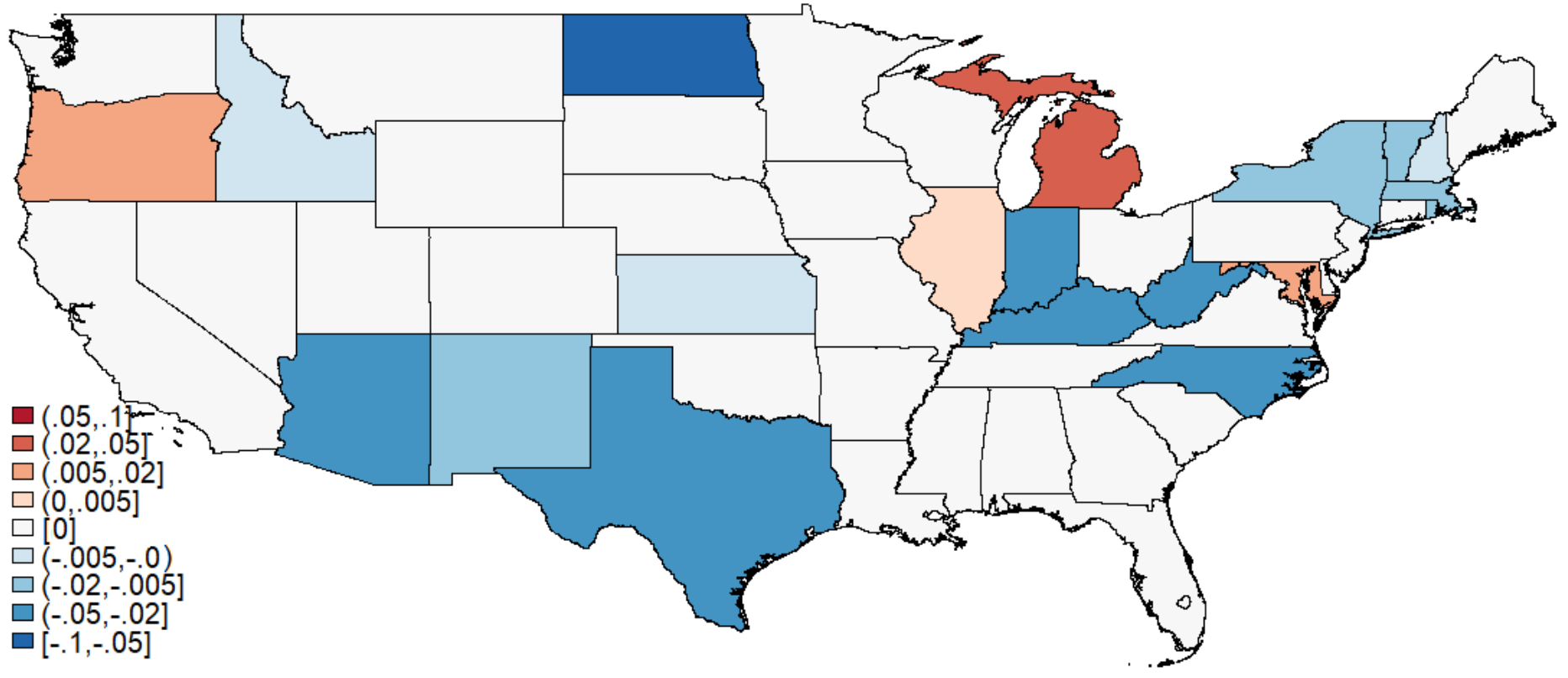




\section{Figure 2: Prices Following Large Tax Changes}

Notes: This figure shows the impact on product prices of a one percentage point or greater change in corporate tax rate over time (scaled by the actual change of tax). The figure plots coefficients $\beta_{n}$ from the following specification: $\ln \left(p_{i, f, r, s, t}\right)=\alpha_{s, t}+\alpha_{i, r, s}+\sum_{n=-3}^{n=4} \beta_{n} \mathbb{1}[t=n] \times \Delta \ln \left(1-\tau_{f, t}^{c}\right)+\gamma_{1} X_{i, t}+\gamma_{2} X_{f, t}+\varepsilon_{i, f, r, s, t}$. The solid line denotes point estimates. The shaded area denotes a $95 \%$ confidence interval. Source: Nielsen and GS1.

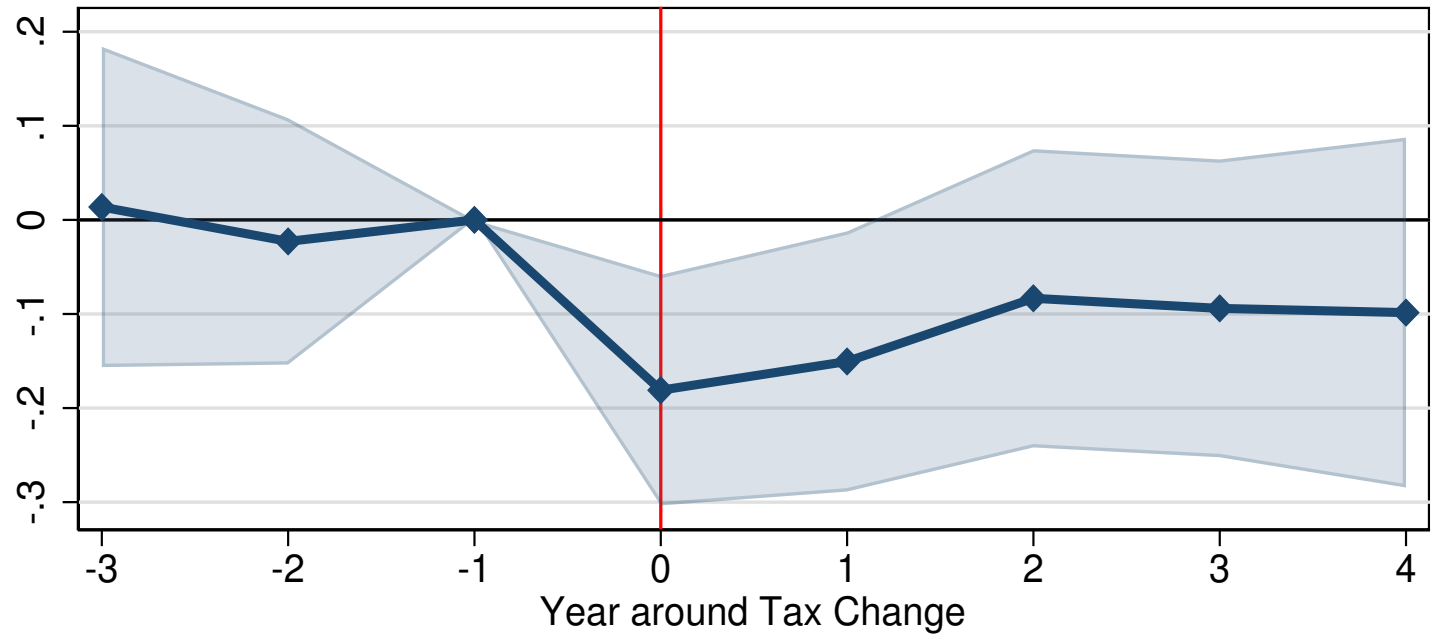




\section{Figure 3: Corporate Taxes and Retail Prices}

Notes: This figure shows percentile binned scatter plots of changes in prices $\Delta \log \left(\right.$ Price $\left._{t}\right)$ and changes in corporate tax rates $\Delta \log \left(1-\tau_{c, t}\right)$, inclusive of federal and state taxes. The left panel shows results for C-corporations, which pay corporate tax rate, while the right panel shows results for S-corporations, which pay at individual income tax rates. Retailer by sold-state by year fixed effects are absorbed. Source: Nielsen and GS1.

\section{C-corporations}

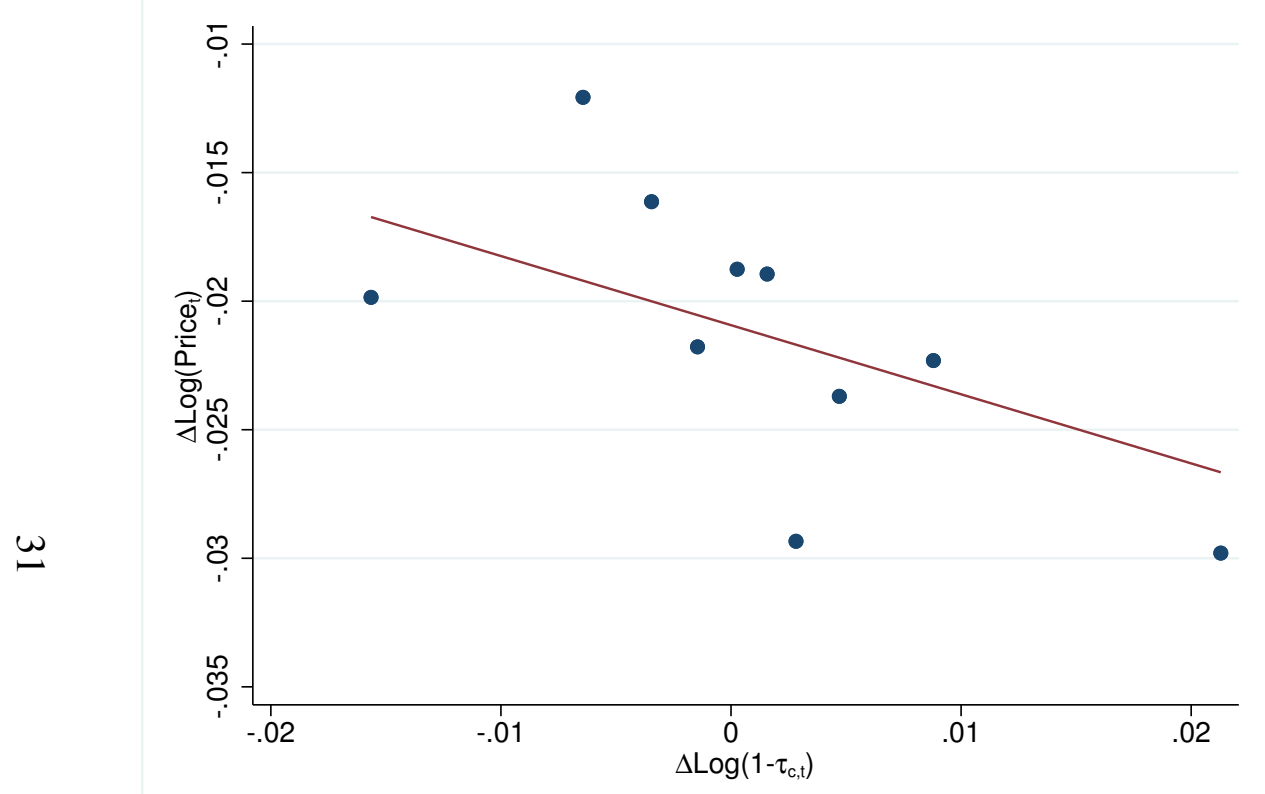

S-corporations

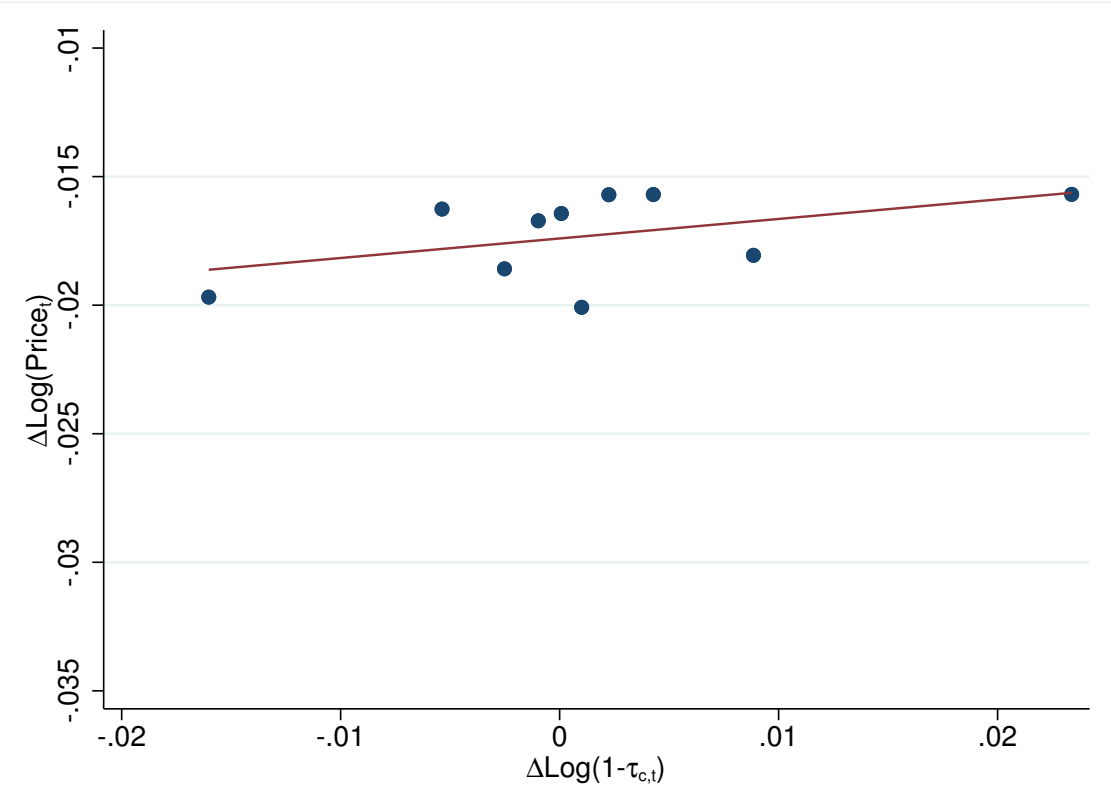




\section{Table 1: Summary Statistics}

This table shows summary statistics for the main analysis sample for C-corps. Observations are at the UPC - retailer chain - sold-state - year level. The sale-weighted price is the average price of one UPC sold by a particular retailer at a state in one year, and it is weighted by the sold quantities. Tax rates are inclusive of federal rates. The sales are the dollar sales of a UPC product sold by a retailer in a state in a given year. Other variables are defined in the Appendix Table A.1. Summary statistics for S-corps are in Appendix Table A.3. Source: Nielsen and GS1.

\begin{tabular}{lccccc}
\hline \hline & \multicolumn{5}{c}{ C-Corp Sample } \\
& Mean & Std. Dev. & $25^{\text {th }}$ Pctl. & Median & $75^{\text {th }}$ Pctl. \\
\hline Sale-weighted Price & 6.00 & 6.81 & 2.61 & 4.49 & 7.52 \\
Corporate Tax Rate & 0.41 & 0.02 & 0.40 & 0.42 & 0.43 \\
Personal Income Tax Rate & 0.33 & 0.09 & 0.28 & 0.35 & 0.40 \\
Log(State Government's General Revenue) & 18.21 & 0.78 & 17.67 & 18.13 & 18.82 \\
Log(State Government's Total Revenue) & 18.38 & 0.83 & 17.72 & 18.34 & 19.09 \\
State's Budget Balance & -0.01 & 0.21 & -0.05 & 0.03 & 0.11 \\
Log(State GDP) & 13.55 & 0.79 & 13.01 & 13.60 & 14.17 \\
Investment & 2.30 & 2.54 & 0.00 & 0.70 & 4.00 \\
Unemployment Rate & 6.92 & 2.10 & 5.30 & 6.50 & 8.50 \\
UI Rate & 7.95 & 1.84 & 6.20 & 8.50 & 8.90 \\
UI Base Wage (Thousands) & 12.91 & 8.02 & 8.00 & 8.50 & 13.00 \\
Property Tax Share & 0.00 & 0.01 & 0.00 & 0.00 & 0.01 \\
Property Apportionment Rate & 7.74 & 11.18 & 0.00 & 0.00 & 25.00 \\
Payroll Apportionment Rate & 7.74 & 11.18 & 0.00 & 0.00 & 25.00 \\
Sales Apportionment Rate & 84.50 & 22.41 & 50.00 & 100.00 & 100.00 \\
\hline Observations & $50,525,599$ & & & & \\
\hline \hline
\end{tabular}


Table 2: Corporate Taxes and Retail Prices

The table shows the relationship between retail prices and corporate taxes using OLS regressions. Retail prices are measured in the geographic location where a good is sold. Corporate taxes are measured via an estimate of tax nexus. The inclusion of controls and fixed effects is denoted beneath each specification. Controls include logged forms of state revenue, state GDP, the unemployment insurance base wage rate and the levels of insurance rates, state unemployment rates, and unemployment compensation. Regressions weighted by the inverse hyperbolic sine of product sales. The sample is restricted to firms that we can identify as $\mathrm{C}$-corporations and headquartered in states with corporate taxes. Standard errors are clustered at the firm year and retailer levels. Source: Nielsen and GS1. * $p<.1, * * p<.05, * * * p<.01$.

\begin{tabular}{lccccc}
\hline \hline & $\begin{array}{c}(1) \\
\log (\text { Price })\end{array}$ & $\begin{array}{c}(2) \\
\log (\text { Price })\end{array}$ & $\begin{array}{c}(3) \\
\log (\text { Price })\end{array}$ & $\begin{array}{c}(4) \\
\log (\text { Price })\end{array}$ & $\begin{array}{c}(5) \\
\log (\text { Price })\end{array}$ \\
\hline $\log \left(1-\tau^{c}\right)$ & $-0.325^{* * *}$ & $-0.322^{* * *}$ & $-0.246^{* * *}$ & $-0.245^{* * *}$ & $-0.243^{* * *}$ \\
& $(0.107)$ & $(0.106)$ & $(0.0927)$ & $(0.0925)$ & $(0.0921)$ \\
\hline Controls & $\mathbf{X}$ & $\mathbf{X}$ & $\mathbf{X}$ & $\mathbf{X}$ & $\mathbf{X}$ \\
UPC $\times$ Retailer $\times$ Sold State & $\mathbf{X}$ & $\mathbf{X}$ & $\mathbf{X}$ & $\mathbf{X}$ & $\mathbf{X}$ \\
Year & $\mathbf{X}$ & & & & \\
Sold State $\times$ Year & & $\mathbf{X}$ & $\mathbf{X}$ & $\mathbf{X}$ & \\
$\begin{array}{l}\text { Retailer } \times \text { Year } \\
\text { Sold State } \times \text { Retailer } \times \text { Year }\end{array}$ & & & & & $\mathbf{X}$ \\
Observations & $50,525,599$ & $50,525,599$ & $50,525,599$ & $50,525,599$ & $50,525,599$ \\
\hline \hline
\end{tabular}




\section{Table 3: State Level CPI and Corporate Taxes}

State level inflation data are constructed from BLS MSA level and regional level CPI data. MSAs are split into counties and population weighted to construct a composite state index when multiple MSAs are present in a single state. Regression spans 1981 to 2017. $\tau_{c}$ measures state level corporate tax rates inclusive of federal rates. Controls include two lags of annual averages of state unemployment rates and annual state-level economic coincident indicators from the Federal Reserve. Standard errors are clustered at the state level. ${ }^{*} p<.1,{ }^{* *} p<.05, * * * p<.01$.

\begin{tabular}{lcccc}
\hline \hline & $(1)$ & $(2)$ & $(3)$ & $(4)$ \\
& Inflation & Inflation & Inflation & Inflation \\
\hline $\log \left(1-\tau_{c}\right)$ & $-0.0259^{* * *}$ & $-0.0334^{* * *}$ & $-0.0146^{* *}$ & $-0.0171^{* *}$ \\
& $(0.00349)$ & $(0.00258)$ & $(0.00721)$ & $(0.00837)$ \\
\hline State & & $\mathbf{X}$ & $\mathbf{X}$ & $\mathbf{X}$ \\
Year & & & $\mathbf{X}$ & $\mathbf{X}$ \\
Economic Controls & & & & $\mathbf{X}$ \\
Observations & 1,785 & 1,785 & 1,785 & 1,734 \\
\hline \hline
\end{tabular}




\section{Table 4: Placebo Estimates: S-Corporations}

The table shows placebo estimates by repeating the main analysis for S-corporations, which do not pay corporate taxes. Retail prices are measured in the geographic location where a good is sold. Corporate taxes are measured via an estimate of tax nexus. The inclusion of controls and fixed effects is denoted beneath each specification. Controls include logged forms of state revenue, state GDP, the unemployment insurance base wage rate and the levels of insurance rates, state unemployment rates, and unemployment compensation. Regressions weighted by the inverse hyperbolic sine of product sales. Standard errors are clustered at the firm year and retailer levels. Source: Nielsen and GS1. ${ }^{*} p<.1,{ }^{* *} p<.05,{ }^{* * *} p<.01$.

\begin{tabular}{lccccc}
\hline \hline & $(1)$ & $(2)$ & $(3)$ & $(4)$ & $(5)$ \\
& $\log ($ Price $)$ & $\log ($ Price $)$ & $\log ($ Price $)$ & $\log ($ Price $)$ & $\log ($ Price $)$ \\
\hline $\log \left(1-\tau^{c}\right)$ & 0.120 & 0.108 & 0.0385 & 0.0383 & 0.0348 \\
& $(0.111)$ & $(0.109)$ & $(0.0997)$ & $(0.0997)$ & $(0.0992)$ \\
\hline Controls & $\mathbf{X}$ & $\mathbf{X}$ & $\mathbf{X}$ & $\mathbf{X}$ & $\mathbf{X}$ \\
UPC $\times$ Retailer $\times$ Sold State & $\mathbf{X}$ & $\mathbf{X}$ & $\mathbf{X}$ & $\mathbf{X}$ & $\mathbf{X}$ \\
Year & $\mathbf{X}$ & & & & \\
Sold State $\times$ Year & & $\mathbf{X}$ & & $\mathbf{X}$ & \\
Retailer $\times$ Year & & & $\mathbf{X}$ & $\mathbf{X}$ & $\mathbf{X}$ \\
Sold State $\times$ Retailer $\times$ Year & & & & & $28,919,249$ \\
Observations & $28,919,249$ & $28,919,249$ & $28,919,249$ & $28,919,249$ & 28, \\
\hline \hline
\end{tabular}




\section{Table 5: Placebo Estimates: Personal Income Taxes}

The table replicates the analysis in Table 2 using personal incomes taxes, which C-corporations do not pay. Retail prices are measured in the geographic location where a good is sold. Personal taxes are measured at the state in which a company is headquartered. The inclusion of controls and fixed effects is denoted beneath each specification. Controls include logged forms of state revenue, state GDP, the unemployment insurance base wage rate and the levels of insurance rates, state unemployment rates, and unemployment compensation. The sample is restricted to firms that we can identify as C-corporations and headquartered in states with corporate taxes. Standard errors are clustered at the firm year and retailer levels. Source: Nielsen and GS1. $* p<.1, * * p<.05, * * * p<.01$.

\begin{tabular}{lccccc}
\hline \hline & $(1)$ & $(2)$ & $(3)$ & $(4)$ & $(5)$ \\
& $\log ($ Price $)$ & $\log ($ Price $)$ & $\log ($ Price $)$ & $\log ($ Price $)$ & $\log ($ Price $)$ \\
\hline $\log \left(1-\tau^{p}\right)$ & 0.0204 & 0.0198 & -0.00604 & -0.00578 & -0.00732 \\
& $(0.0544)$ & $(0.0540)$ & $(0.0483)$ & $(0.0483)$ & $(0.0480)$ \\
\hline Controls & $\mathbf{X}$ & $\mathbf{X}$ & $\mathbf{X}$ & $\mathbf{X}$ & $\mathbf{X}$ \\
UPC $\times$ Retailer $\times$ Sold State & $\mathbf{X}$ & $\mathbf{X}$ & $\mathbf{X}$ & $\mathbf{X}$ & $\mathbf{X}$ \\
Year & $\mathbf{X}$ & & & & $\mathbf{X}$ \\
Sold State $\times$ Year & & $\mathbf{X}$ & & $\mathbf{X}$ & \\
Retailer $\times$ Year & & & $\mathbf{X}$ & & $\mathbf{X}$ \\
Sold State $\times$ Retailer $\times$ Year & & & & & $50,525,599$ \\
Observations & $50,525,599$ & $50,525,599$ & $50,525,599$ & $50,525,599$ & 50,50 \\
\hline \hline
\end{tabular}




\section{Table 6: Corporate Taxes, Retail Prices, with Additional State Controls}

The table shows the relationship between corporate taxes and retail prices across products, adding additional state-level controls. State-level controls are measured at the state headquarter level. Retail prices are measured in the geographic location where a good is sold. Corporate taxes are measured via an estimate of tax nexus. Included are state-level tax incentive related state-level variables are those used in Heider and Ljungqvist (2015): (1) investment tax credits (2) upper and lower bounds of R\&D tax credits (3) job creation tax credit indicators and (4) job creation grant indicators. The inclusion of controls and fixed effects is denoted beneath each specification. Controls include logged forms of state revenue, state GDP, the unemployment insurance base wage rate and the levels of insurance rates, state unemployment rates, and unemployment compensation. Regressions weighted by the inverse hyperbolic sine of product sales. The sample is restricted to firms that we can identify as C-corporations and headquartered in states with corporate taxes. Standard errors are clustered at the firm year and retailer levels.

Source: Nielsen and GS1. $* p<.1, * * p<.05, * * * p<.01$.

\begin{tabular}{|c|c|c|c|c|c|}
\hline & (1) & (2) & (3) & (4) & (5) \\
\hline & $\log ($ Price $)$ & Log(Price) & Log(Price) & Log(Price) & $\log ($ Price $)$ \\
\hline \multirow[t]{2}{*}{$\log \left(1-\tau^{c}\right)$} & $-0.275^{* *}$ & $-0.274^{* *}$ & $-0.209^{* *}$ & $-0.209^{* *}$ & $-0.208^{* *}$ \\
\hline & $(0.105)$ & $(0.105)$ & $(0.0898)$ & $(0.0899)$ & $(0.0895)$ \\
\hline Controls & $\mathbf{X}$ & $\mathbf{X}$ & $\mathbf{X}$ & $\mathbf{X}$ & $\mathbf{X}$ \\
\hline UPC $\times$ Retailer $\times$ Sold State & $\mathbf{X}$ & $\mathbf{X}$ & $\mathbf{X}$ & $\mathbf{X}$ & $\mathbf{X}$ \\
\hline Year & $\mathbf{X}$ & & & & \\
\hline Sold State $\times$ Year & & $\mathbf{X}$ & & $\mathbf{X}$ & \\
\hline Retailer $\times$ Year & & & $\mathbf{X}$ & $\mathbf{X}$ & \\
\hline Sold State $\times$ Retailer $\times$ Year & & & & & $\mathbf{X}$ \\
\hline Observations & $50,525,599$ & $50,525,599$ & $50,525,599$ & $50,525,599$ & $50,525,599$ \\
\hline
\end{tabular}




\section{Table 7: Corporate Taxes and Retail Prices - Pass-through Heterogeneity}

The table shows the relationship between corporate taxes and retail prices across products with different average customer incomes and prices. Logged household income is measured as the sales-weighted average household income of households purchasing a given UPC (median logged household income is 11.06 in our sample). Average prices measured at a UPC level (median logged average price is 1.52 in our sample). Retail prices are measured in the geographic location where a good is sold. Corporate taxes are measured via an estimate of tax nexus. The inclusion of controls and fixed effects is denoted beneath each specification. Controls include logged forms of state revenue, state GDP, the unemployment insurance base wage rate and the levels of insurance rates, state unemployment rates, and unemployment compensation. Regressions weighted by the inverse hyperbolic sine of product sales. The sample is restricted to firms that we can identify as C-corporations and headquartered in states with corporate taxes. Standard errors are clustered at the firm year and retailer levels. Source: Nielsen and GS1. $* p<.1, * * p<.05, * * * p<.01$.

\begin{tabular}{lccccc}
\hline \hline & $(1)$ & $(2)$ & $(3)$ & $(4)$ & $(5)$ \\
& $\log ($ Price $)$ & $\log ($ Price $)$ & $\log ($ Price $)$ & $\log ($ Price $)$ & $\log ($ Price $)$ \\
\hline $\log \left(1-\tau^{c}\right)$ & $12.89^{* * *}$ & $12.86^{* * *}$ & $11.60^{* * *}$ & $11.61^{* * *}$ & $11.66^{* * *}$ \\
& $(2.780)$ & $(2.763)$ & $(2.511)$ & $(2.509)$ & $(2.514)$ \\
$\log \left(1-\tau^{c}\right) \times \log ($ Avg HH Income $)$ & $-1.197^{* * *}$ & $-1.193^{* * *}$ & $-1.072^{* * *}$ & $-1.074^{* * *}$ & $-1.078^{* * *}$ \\
& $(0.255)$ & $(0.253)$ & $(0.230)$ & $(0.230)$ & $(0.231)$ \\
\hline $\log \left(1-\tau^{c}\right)$ & $0.335^{* *}$ & $0.336^{* *}$ & $0.333^{* *}$ & $0.334^{* *}$ & $0.334^{* *}$ \\
& $(0.143)$ & $(0.142)$ & $(0.129)$ & $(0.129)$ & $(0.128)$
\end{tabular}

\begin{tabular}{lccccc}
$\log \left(1-\tau^{c}\right) \times \log ($ Avg Price $)$ & $-0.473^{* * *}$ & $-0.471^{* * *}$ & $-0.415^{* * *}$ & $-0.415^{* * *}$ & $-0.414^{* * *}$ \\
& $(0.100)$ & $(0.100)$ & $(0.0963)$ & $(0.0963)$ & $(0.0957)$ \\
\hline Controls & $\mathbf{X}$ & $\mathbf{X}$ & $\mathbf{X}$ & $\mathbf{X}$ & $\mathbf{X}$ \\
UPC $\times$ Retailer $\times$ Sold State & $\mathbf{X}$ & $\mathbf{X}$ & $\mathbf{X}$ & $\mathbf{X}$ & $\mathbf{X}$ \\
Year & $\mathbf{X}$ & & & & \\
Sold State $\times$ Year & & $\mathbf{X}$ & & $\mathbf{X}$ & \\
$\begin{array}{l}\text { Retailer } \times \text { Year } \\
\text { Sold State } \times \text { Retailer } \times \text { Year }\end{array}$ & & & $\mathbf{X}$ & $\mathbf{X}$ & $\mathbf{X}$ \\
Observations & $50,525,599$ & $50,525,599$ & $50,525,599$ & $50,525,599$ & $50,525,599$ \\
\hline \hline
\end{tabular}




\section{Table 8: Corporate Taxes, Retail Prices and Market Concentration}

The table shows the relationship between retail prices, corporate taxes and market concentration. Retail prices are measured in the geographic location where a good is sold. Corporate taxes are measured via an estimate of tax nexus. The inclusion of controls and fixed effects is denoted beneath each specification. Controls include logged forms of state revenue, state GDP, the unemployment insurance base wage rate and the levels of insurance rates, state unemployment rates, and unemployment compensation. Regressions weighted by the inverse hyperbolic sine of product sales. We define each combination of product module-retailer-state as a separate market and calculate the HHI for each of them at different years. The sample is restricted to firms that we can identify as C-corporations and that have market concentration information. Standard errors are clustered at the firm year and retailer levels. Source: Nielsen and GS1. ${ }^{*} p<.1, * * p<.05, * * * p<.01$.

\begin{tabular}{lccccc}
\hline \hline & $(1)$ & $(2)$ & $(3)$ & $(4)$ & $(5)$ \\
& $\log ($ Price $)$ & $\log ($ Price $)$ & $\log ($ Price $)$ & $\log ($ Price $)$ & $\log ($ Price $)$ \\
\hline $\log \left(1-\tau^{c}\right)$ & $-0.219^{* *}$ & $-0.216^{* *}$ & $-0.147^{*}$ & $-0.146^{*}$ & $-0.145^{*}$ \\
& $(0.0966)$ & $(0.0957)$ & $(0.0808)$ & $(0.0806)$ & $(0.0802)$ \\
& & & & & $-0.501^{* * *}$ \\
$\log \left(1-\tau^{c}\right)^{*}$ Product Group HHI & $-0.534^{* * *}$ & $-0.533^{* * *}$ & $-0.504^{* * *}$ & $-0.503^{* * *}$ & $-0.161)$ \\
\hline Controls & $(0.165)$ & $(0.165)$ & $(0.161)$ & $(0.161)$ & $\mathbf{X}$ \\
UPC $\times$ Retailer $\times$ Sold State & $\mathbf{X}$ & $\mathbf{X}$ & $\mathbf{X}$ & $\mathbf{X}$ & $\mathbf{X}$ \\
Year & $\mathbf{X}$ & $\mathbf{X}$ & $\mathbf{X}$ & $\mathbf{X}$ & $\mathbf{X}$ \\
Sold State $\times$ Year & $\mathbf{X}$ & & & $\mathbf{X}$ & $\mathbf{X}$ \\
Retailer $\times$ Year & & $\mathbf{X}$ & & & $\mathbf{X}$ \\
Sold State $\times$ Retailer $\times$ Year & & & & & \\
Observations & $50,194,676$ & $50,194,676$ & $50,194,676$ & $50,194,676$ & $50,194,676$ \\
\hline \hline
\end{tabular}




\section{A Model and Incidence}

\section{A.1 Model Details}

This appendix provides further context for our motivating model, and derives the main expression in Section 2.2 which provides a basis for our empirical strategy and subsequent analysis of incidence. We assume firms operate in a monopolistically competitive environment similar to De Loecker (2011) and Suárez Serrato and Zidar (2016). Firms are endowed with some productivity level $B$, and combine labor, $L$ and capital $K$ to produce output $y$ with the following production function,

$$
y=B \cdot L^{\gamma} K^{1-\gamma}
$$

Firms take input prices as given and the output price $p$ is given by an inverse demand curve from CES demand with $y=I \cdot\left(\frac{p}{\bar{p}}\right)^{\varepsilon}$, where $\bar{p}$ is the price level and is normalized to 1 and $\varepsilon<0$, is the demand elasticity. The firm maximizes profits, which are taxed at a rate $\tau$. The firm thus solves

$$
\max _{L, K}(1-\tau) \cdot(p \cdot y-w \cdot L)-\rho \cdot K
$$

where $w$ is the wage rate for labor, and $\rho$ is the rate of return for capital.

Inserting the price equation into the objective function yields the firm's problem:

$$
\max _{L, K}(1-\tau)\left(y^{\frac{1}{\mu}} I^{-\frac{1}{\varepsilon}}-w \cdot L\right)-\rho \cdot K
$$

Where the markup $\mu \equiv\left[\frac{1}{\varepsilon}+1\right]^{-1}$ is constant due to CES demand. The solution yields for $L$ :

$$
\frac{y^{\frac{1}{\mu}}}{\mu} \cdot \frac{\gamma}{L} \cdot I^{-\frac{1}{\varepsilon}}=w
$$

We solve for $K$ and obtain a similar expression:

$$
\frac{y^{\frac{1}{\mu}}}{\mu} \cdot \frac{1-\gamma}{K} \cdot I^{-\frac{1}{\varepsilon}}=\rho\left(\frac{1}{1-\tau}\right)
$$

Combining 8 and 10 with the firm's production function $y=B L^{\gamma} K^{1-\gamma}$ and solving for $p$ 
yields the equation below, which directly motivates our main estimating equation and empirical strategy.

$$
\ln (p)=-(1-\gamma) \ln (1-\tau)+(1-\gamma) \ln (\rho)+\gamma \ln (w)+Z
$$

where $Z$ is a constant and given by

$$
Z=-\ln (B)-\ln \left(\frac{1}{\varepsilon}+1\right)-(1-\gamma) \ln (1-\gamma)-\gamma \ln (\gamma)
$$

\section{A.2 Incidence Calculations}

We further extend the framework of Fuest, Peichl and Siegloch (2018) and consider three agents in this setting: the firm owner at state $h$, the worker from state $h$ and the consumer from state $s$ $(h \neq s)$. We evaluate the tax burden by relating the welfare change of consumers paying higher prices induced by the corporate tax change from other states to the sum of welfare changes of firm owners, workers and consumers.

The firm owner's welfare change relates to the following value function:

$$
V_{f}=\max _{K, L_{h}}\left(1-\tau_{h}^{c}\right)\left(p F\left(K, L_{h}\right)-w_{h} L_{h}\right)-r K
$$

Here the $K$ is capital, $L_{h}$ is the local labor amount employed by the firm at state $h$ and $r$ is the return rate on capital. Taking the differential, and noting that $\frac{\partial V_{f}}{\partial L_{h}}=0, \frac{\partial V_{f}}{\partial K}=0$ from optimization, we have $d V_{f}$ is equivalent to:

$$
\frac{\partial V_{f}}{\partial K} \cdot\left(K_{p} d p+K_{\tau_{h}^{c}} d \tau_{h}^{c}\right)+\frac{\partial V_{f}}{\partial L_{h}} \cdot\left(L_{h, p} d p+L_{h, \tau_{h}^{c}} d \tau_{h}^{c}\right)+\frac{\partial V_{f}}{\partial p} \cdot d p+\frac{\partial V_{f}}{\partial \tau_{h}^{c}} \cdot d \tau_{h}^{c}+\frac{\partial V_{f}}{\partial w_{h}} \cdot d w_{h}
$$

that is,

$$
\frac{\partial V_{f}}{\partial p} \cdot d p+\frac{\partial V_{f}}{\partial \tau_{h}^{c}} \cdot d \tau_{h}^{c}+\frac{\partial V_{f}}{\partial w_{h}} \cdot d w_{h}
$$

The term above can be rewritten as:

$$
\left(1-\tau_{h}^{c}\right) F\left(K, L_{h}\right) d p-\left(p F\left(K, L_{h}\right)-w_{h} L_{h}\right) d \tau_{h}^{c}-\left(1-\tau_{h}^{c}\right) L_{h} d w_{h}
$$


The consumer's welfare change stems from each consumer maximizing the utility function $U\left(C_{s}, L_{s}\right)$, subject to the budget constraint: $p \cdot C_{s}=\left(1-\tau^{p}\right) w_{s} L_{s}$, where $p$ is the price for the goods, $C_{s}$ is the quantity purchased, $\tau^{p}$ is the personal income tax, $w_{s}$ is the wage received by consumer and $L_{s}$ is the labor. Since the consumer in our analysis is not from the same producer state where there is a tax shock, we assume the wage and labor supply, $w_{s}$ and $L_{s}$, will not change. The consumer's welfare will be changed only by the price of products purchased. Then, the value function of the consumer is a function of the price:

$$
V_{\text {con }}(p)=U\left(C_{s}, L_{s}\right)-\lambda\left(p C_{s}-\left(1-\tau^{p}\right) w_{s} L_{s}\right)=U\left(C_{s}, L_{s}\right)-\left(p C_{s}-\left(1-\tau^{p}\right) w_{s} L_{s}\right)
$$

Note that $\lambda=1$ is due to the assumption that the marginal utility of income is normalized to unity. Taking the differential of the value function, and noting that here $\frac{\partial V_{\text {cons }}}{\partial L_{s}}=0, \frac{\partial V_{\text {cons }}}{\partial C_{s}}=0$ are due to optimization, we have:

$$
d V_{c o n_{s}}=\frac{\partial V_{\text {con }_{s}}}{\partial C_{s}} C_{s, p} \cdot d p+\frac{\partial V_{c o n_{s}}}{\partial L_{s}} L_{s, p} \cdot d p+\frac{\partial V_{c o n_{s}}}{\partial p} \cdot d p=\frac{\partial V_{c o n_{s}}}{\partial p} \cdot d p=-C_{s} \cdot d p
$$

The local worker in the producer state maximizes the utility function, $U\left(C_{h}, L_{h}\right)$, subject to the constraint, $p C_{h}=\left(1-\tau_{h}^{p}\right) w_{h} L_{h}$. We assume locally that the price of goods will not change, therefore welfare of the worker is changed only due to the wage, $w_{h}$, received, and the value function of the worker is a function of the wage. The corresponding value function is:

$$
V_{w k r_{h}}\left(w_{h}\right)=U\left(C_{h}, L_{h}\right)-\lambda\left(p C_{h}-\left(1-\tau_{h}^{p}\right) w_{h} L_{h}\right)=U\left(C_{h}, L_{h}\right)-\left(p C_{h}-\left(1-\tau_{h}^{p}\right) w_{h} L_{h}\right)
$$

where $\lambda$ is unity for the same normalization purpose as in the consumer problem. Taking the differential of the value function, where again $\frac{\partial V_{w k r_{h}}}{\partial L_{h}}=0, \frac{\partial V_{w k r_{h}}}{\partial C_{h}}=0$ due to worker optimization, we have:

$$
d V_{w k r_{h}}=\frac{\partial V_{w k r_{h}}}{\partial C_{h}} C_{h, w_{h}} \cdot d w_{h}+\frac{\partial V_{w k r_{h}}}{\partial L_{h}} L_{h, w_{h}} \cdot d w_{h}+\frac{\partial V_{w k r_{h}}}{\partial w_{h}} \cdot d w_{h}=\frac{\partial V_{w k r_{h}}}{\partial w_{h}} \cdot d w_{h}=\left(1-\tau_{h}^{p}\right) L_{h} \cdot d w_{h}
$$

We can thus write the share of the tax burden on the consumer, the firm and the worker using 
the above framework. The tax burden share of the consumer would be the following formula:

$$
I_{c o n_{s}}=\frac{d V_{\text {con }_{s}}}{d V_{\text {con }_{s}}+d V_{\text {wrk }_{h}}+d V_{f}}
$$

As a consequence, the incidence on consumers is given by:

$$
I_{c o n_{s}}=\frac{-C_{s} \frac{d p}{d \tau}}{-C_{s} \frac{d p}{d \tau}+\left(\tau_{h}^{c}-\tau_{h}^{p}\right) L_{h} \frac{d w_{h}}{d \tau}+\left(1-\tau_{h}^{c}\right) F\left(K, L_{h}\right) \frac{d p}{d \tau}-\left(p F\left(K, L_{h}\right)-w_{h} L_{h}\right)}
$$

The paper estimates the price elasticity with respect to corporate tax as: $\delta_{p}=\frac{\frac{d p}{p}}{\frac{d(1-\tau)}{1-\tau}}=$ $\frac{d p}{d \tau}\left(-\frac{(1-\tau)}{p}\right)$. The wage elasticity is given by $\delta_{w_{h}}=\frac{\frac{d w_{h}}{w_{h}}}{\frac{d(1-\tau)}{1-\tau}}=\frac{d w_{h}}{d \tau}\left(-\frac{1-\tau}{w_{h}}\right)$. Combining the relevant elasticities into equation (22), we have the incidence formula:

$$
I_{c o n_{s}}=\frac{p C_{s} \delta_{p}}{p C_{s} \delta_{p}-\left(\tau_{h}^{c}-\tau_{h}^{p}\right) w_{h} L_{h} \delta_{w_{h}}-\left(1-\tau_{h}^{c}\right) p F\left(K, L_{h}\right) \delta_{p}-\left(1-\tau_{h}^{c}\right)\left(p F\left(K, L_{h}\right)-w_{h} L_{h}\right)}
$$

Moreover, the consumption share over the output is $s_{c o n}=\frac{p C_{s}}{p F\left(K, L_{h}\right)}$, and the labor share is $s_{\text {labor }}=\frac{w_{h} L_{h}}{p F\left(K, L_{h}\right)}$. Inserting the shares into the incidence, we have:

$$
I_{c o n_{s}}=\frac{s_{c o n} \delta_{p}}{s_{c o n} \delta_{p}-\left(\tau_{h}^{c}-\tau_{h}^{p}\right) s_{\text {labor }} \delta_{w_{h}}-\left(1-\tau_{h}^{c}\right) \delta_{p}-\left(1-\tau_{h}^{c}\right)\left(1-s_{\text {labor }}\right)}
$$

Similarly, the incidence on the worker is given by:

$$
\begin{gathered}
I_{w r k_{h}}=\frac{d V_{w r k_{h}}}{d V_{c o n_{s}}+d V_{w r k_{h}}+d V_{f}} \\
=\frac{-\left(1-\tau_{h}^{p}\right) s_{\text {labor }} \delta_{w_{h}}}{s_{c o n} \delta_{p}-\left(\tau_{h}^{c}-\tau_{h}^{p}\right) s_{\text {labor }} \delta_{w_{h}}-\left(1-\tau_{h}^{c}\right) \delta_{p}-\left(1-\tau_{h}^{c}\right)\left(1-s_{\text {labor }}\right)}
\end{gathered}
$$

And the incidence on the firm owners' can be written:

$$
\begin{gathered}
I_{f}=\frac{d V_{f}}{d V_{c o n_{s}}+d V_{f}+d V_{w r k_{h}}} \\
=\frac{-\left(1-\tau_{h}^{c}\right) \delta_{p}-\left(1-\tau_{h}^{c}\right)\left(1-s_{\text {labor }}\right)+\left(1-\tau_{h}^{c}\right) s_{\text {labor }} \delta_{w_{h}}}{s_{\text {con }} \delta_{p}-\left(\tau_{h}^{c}-\tau_{h}^{p}\right) s_{\text {labor }} \delta_{w_{h}}-\left(1-\tau_{h}^{c}\right) \delta_{p}-\left(1-\tau_{h}^{c}\right)\left(1-s_{\text {labor }}\right)}
\end{gathered}
$$


To quantify the magnitude of the corporate tax pass-through, we use our estimated elasticity $\delta_{p}$ with other economic statistics into the formula above. The parameters we used are:

1) $s_{\text {con }}=0.675$, from BEA's consumption share of GDP;

2) $s_{\text {labor }}=0.5$, from the sector-level estimate of Giandrea and Sprague (2017);

4) $\tau_{h}^{c}=0.42$, as the sum of federal $35 \%$ and state level average $7 \%$ corporate income tax rate;

5) $\tau_{h}^{p}=0.40$, average personal income tax rate including federal and state taxes.

Combined with the estimated price elasticity with respect to the tax in the baseline Table 2, $\delta_{p}=-0.24$, and the implied value of $\delta_{w}=0.3$, we calculate the tax incidence on consumers, firm owners and workers is $52 \%, 20 \%$, and $28 \%$, respectively. Alternatively, if we use the estimates from Table 6 (including additional controls) or Table A.4 (utilizing Nielsen Consumer Panel Homescan data), $\delta_{p}=-0.20$, the tax incidence on consumers, firm owners and workers are $43 \%$, $21 \%$, and $36 \%$, respectively.

\section{B Tax Nexus Definition}

When a firm operates in several states, many states may have the power to tax it. Our analysis takes into account of apportionment of taxable income for multi-state firms. If a firm has activities other than "mere solicitation of orders" in one state, or has a physical presence in that state, this state has the power to tax the firm in that fiscal year. The amount of taxable income for one state is determined by the sale, payroll and property distribution of the firm. Specifically, the share of taxable income a state has power to charge is a weighted average of the share of sale, payroll and property the firm has in that state. The weights for these three factors are different across states by year.

To estimate the effective tax rate of a firm, we supplement our data with the sale and payroll information at the establishment level from Infogroup data. Due to the limitation of the data, we assume that the property share in one state is equal to the payroll share, and approximate the payroll share by the employment share. We follow the approach used by Suárez Serrato and Zidar (2016), and only use the geographical distribution of firms' activity in the first available year to construct 
the apportioned tax rate. That is, we assume that the firms did not reallocate their activity in the following year. As a result, the variation of the effective tax rate comes from the change of tax rate and variation in the tax rules. The tax rate has the following formula:

$$
\tau_{c, t, \text { apportioned }}=\sum_{s}\left(\omega_{\text {sale }, t} \times \theta_{\text {sale }}+\omega_{\text {prop }, t} \times \theta_{\text {prop }}+\omega_{\text {pay }, t} \times \theta_{\text {pay }}\right) \times \tau_{c, s, t}
$$

Where the $\omega_{\text {sale,t }}, \omega_{\text {prop }, t}$ and $\omega_{\text {pay,t }}$ are factor weights on sale, property and payroll at year $t$, the $\theta_{\text {sale }}, \theta_{\text {prop }}$ and $\theta_{\text {pay }}$ are the share of sale, property and payroll of a firm at the first available year. $\tau_{c, s, t}$ is the corporate tax rate at state $s$ in year $t$.

We also provide an alternative definition of tax nexus, following Heider and Ljungqvist (2015). The results using alternative tax incidence are shown in Table A.5, and are largely consistent with our main results.

\section{Nielsen Consumer Panel}

In our main analysis, we use the Nielsen Retail Measurement Services (RMS) data. We replicate our main findings with a sample of the Nielsen Consumer Panel, which surveys consumers rather than retailers. The Nielsen Consumer Panel (NCP; formerly known as 'Homescan' data) contains 40,000-60,000 American households across 52 metropolitan areas, spanning the years of 2004-2017 and covering almost 2 million unique items purchased. The panel is constructed as a representative sample of the American population and is tracked through the inclusion of numerous demographic indicators, including the location of the household.

Nielsen attempts to ensure high levels of participation among households in the panel through regular reminders that go out to households, encouraging them to report purchases and trips fully. Prizes, both monetary and in-kind, are utilized to incentivize high levels of continued engagement among participant households, and households that seem to be reducing levels of reporting are removed from the sample periodically. Including these non-compliers, about $20 \%$ of households exit from the sample each year, with the average tenure in-sample being about 4 years. ${ }^{20}$

The NCP mostly covers trips to pharmacies, grocery stores, and big-box/mass-merchandise

\footnotetext{
${ }^{20}$ Broda and Weinstein (2010) and Einav, Leibtag and Nevo (2010) provide more detail and analysis of the NCP. In general, they find accurate coverage of household spending and non-imputed prices.
} 
stores. Consequently, the products generally span groceries, drugs and sundries, small electronics and household appliances, home furnishings (though generally not large furniture), garden and kitchen equipment, and some soft goods. While somewhat limited in scope (e.g., the data excludes services, rents and mortgages, restaurants), the NCP covers a substantial fraction of household spending on non-services: approximately $\$ 375$ of spending per household per month. This constitutes about $30 \%$ of all household expenditures on goods in the CPI basket. The ultimate matched sample takes account of $65 \%$ annual sales (65\% monthly sale) of the persistent sample and thus, covers $15 \%$ annual sale of the Homescan database. This matched sample also covers $50 \%$ unique UPC in the persistent sample which is $2 \%$ UPC in the Homescan database. 


\section{Figure A.1: State Corporate Taxes Over Time}

Notes: This figure shows corporate tax rates across states in 2004, 2010 and 2017. Maximum corporate tax rates are displayed. The rates do not include federal taxes. Source: Giroud and Rauh (2019) and Tax Foundation.
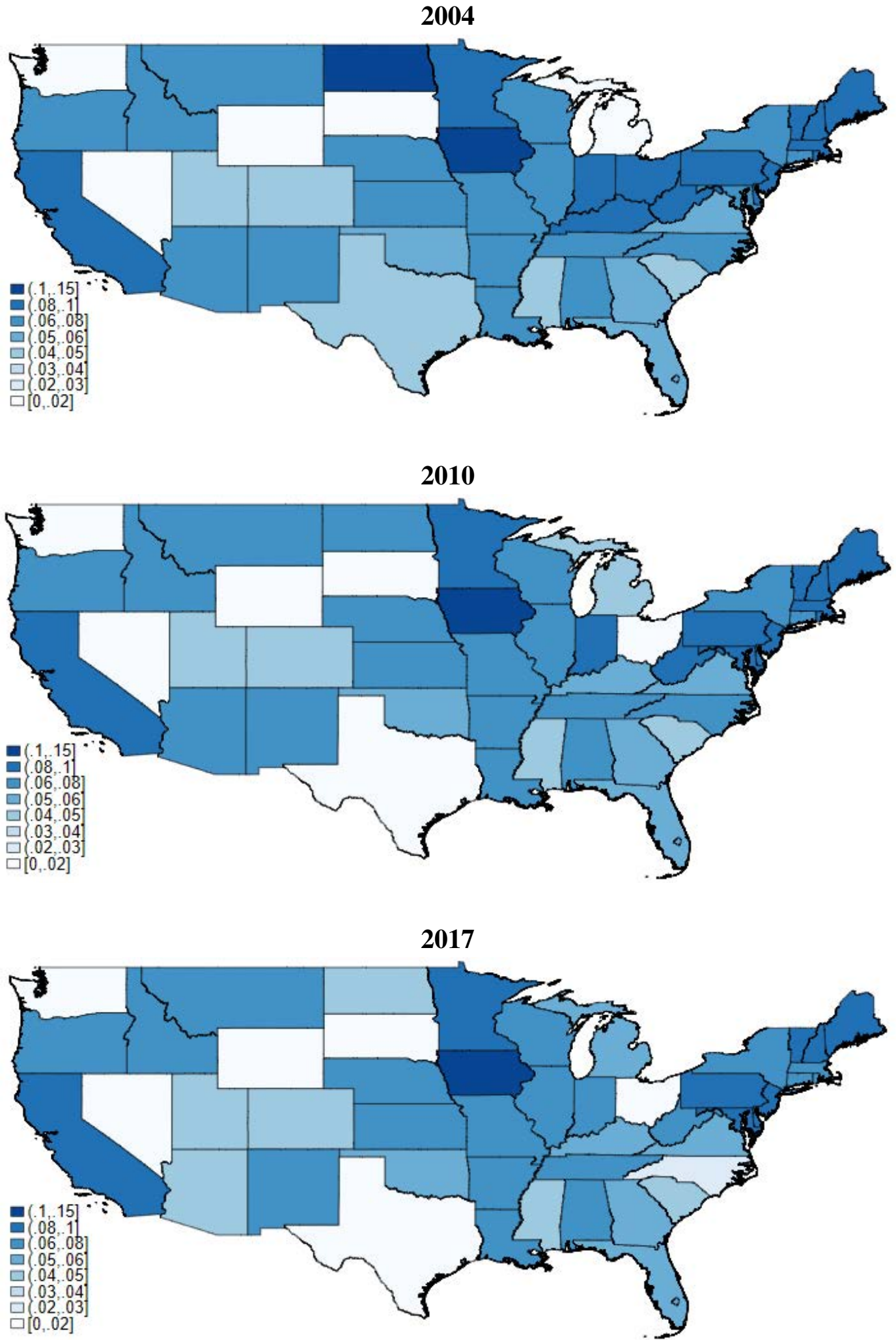


\section{Figure A.2: Distribution of Tax Rates}

Notes: This figure shows the density of state corporate tax rates in 2005 and 2017. Maximum corporate tax rates are displayed. The rates do not include federal taxes. Source: Giroud and Rauh (2019) and Tax Foundation.

2005

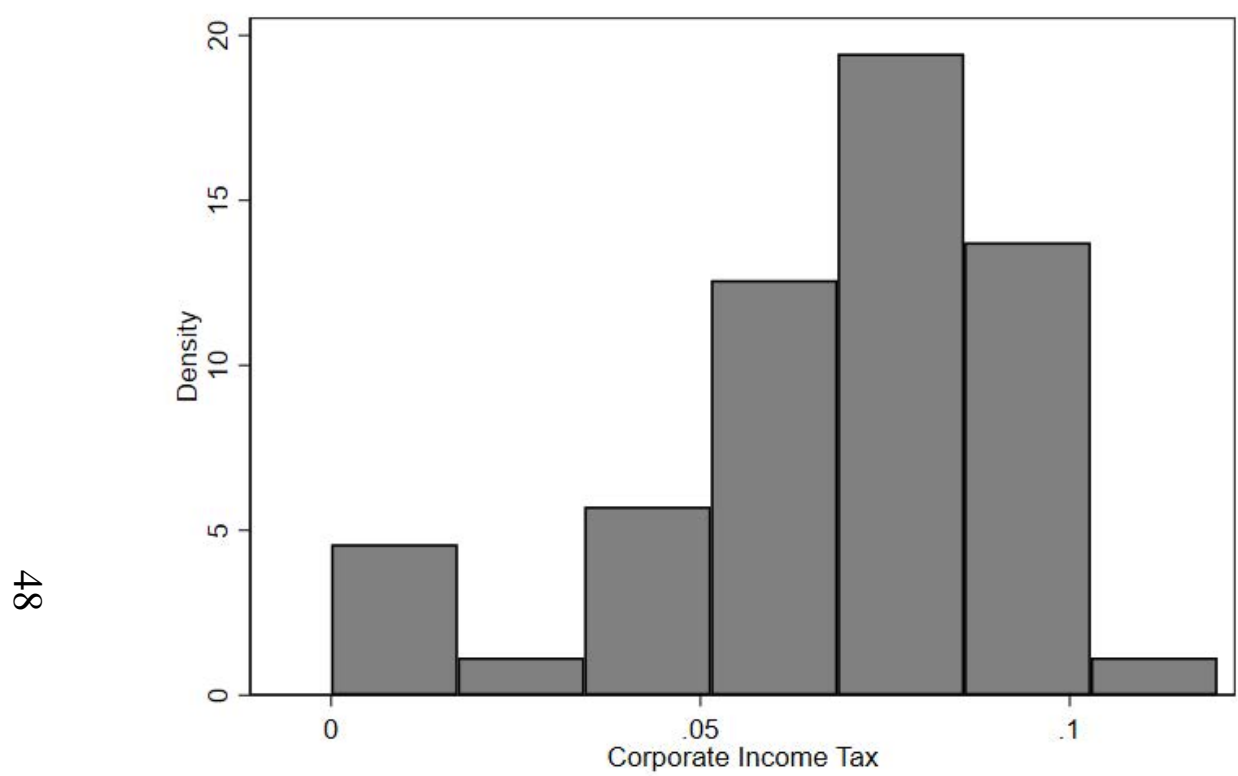

2017

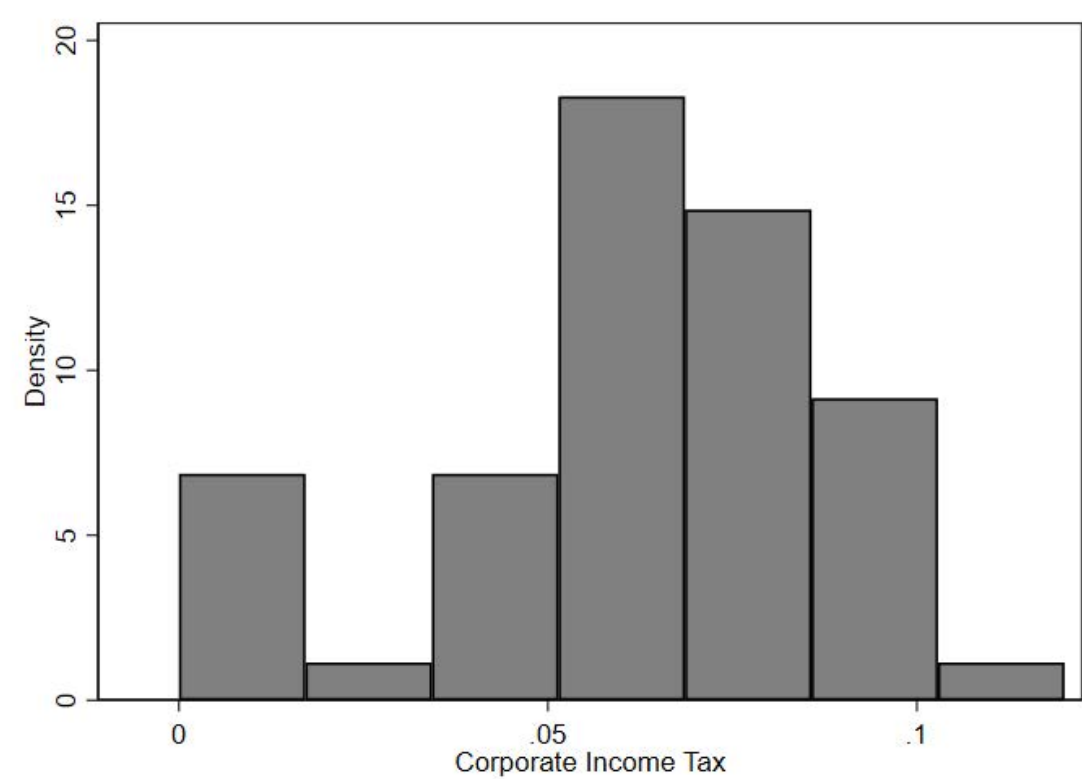


Figure A.3: Distribution of Tax Rate Changes

Notes: This figure shows the change in state corporate tax rates between 2005 and 2017. Source: Giroud and Rauh (2019) and Tax Foundation.

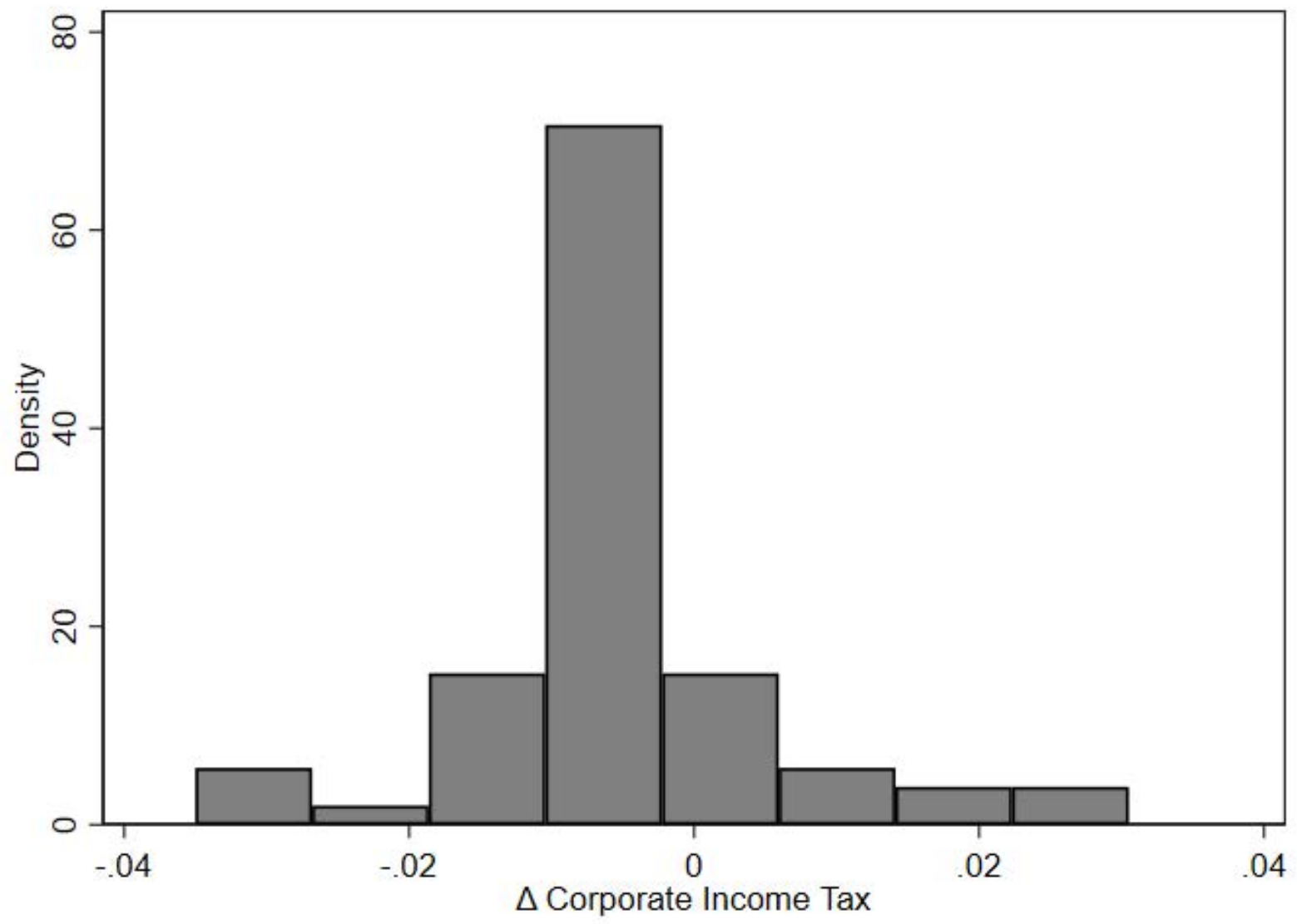




\section{Figure A.4: Fraction of State Tax Revenue from Corporate Taxes}

Notes: This figure plots a map of states labelled according to the fraction of state level tax revenue derived from corporate taxes. Data is from 2010. Source: Tax Foundation.

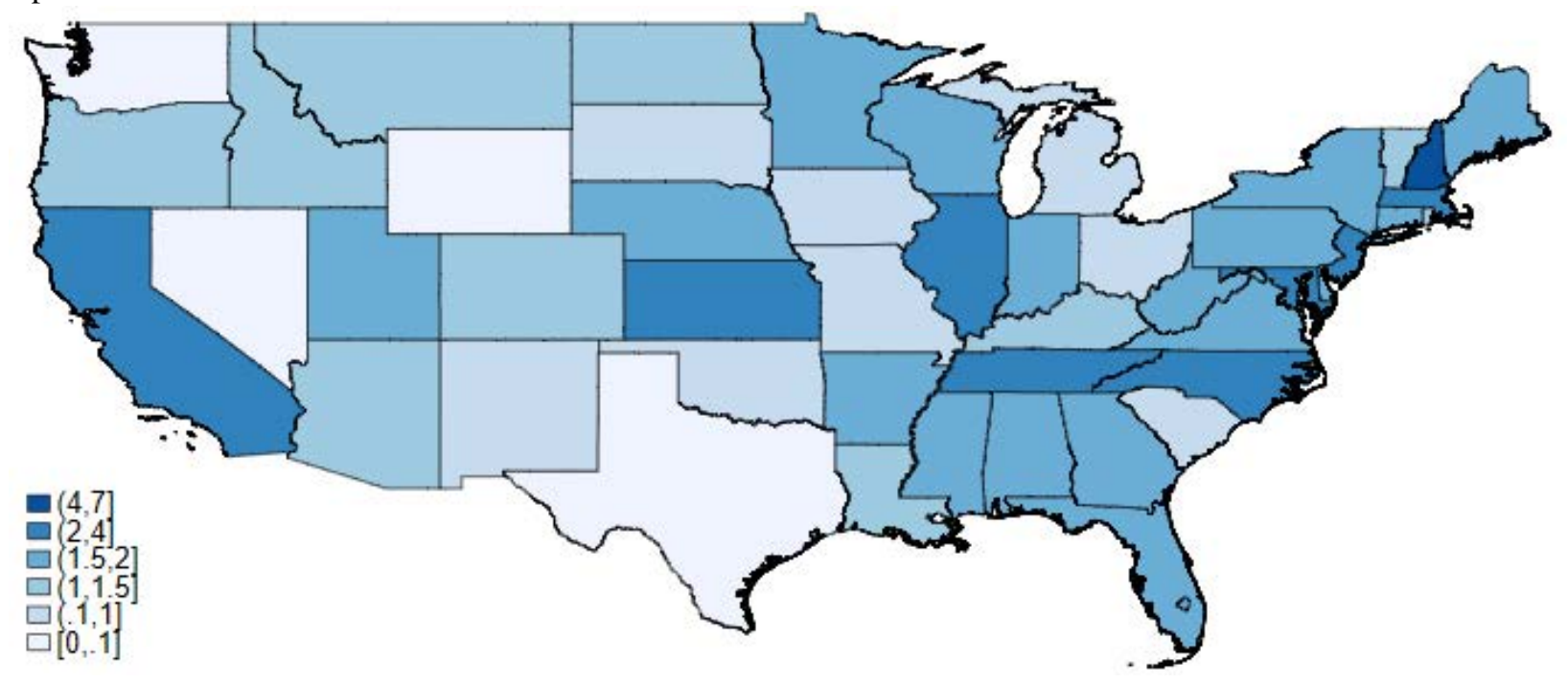


Table A.1: Main Variable Descriptions

\begin{tabular}{|c|c|c|}
\hline Name & Source & Description \\
\hline Price & Nielsen & $\begin{array}{l}\text { Price of a UPC sold by a retailer in a state. The price data } \\
\text { is aggregated to compute the weighted average price of } \\
\text { that item sold at this retailer in each state. The price is } \\
\text { weighted by the quantity sold. }\end{array}$ \\
\hline Corporate Income Tax & Various & $\begin{array}{l}\text { The state corporate income tax rate for each state in } \\
\text { different years. This is obtained from the State Tax } \\
\text { Handbook, the Tax Foundation (2006-2011), the Book } \\
\text { of States, and the state Tax Policy Center (2013-2017) }\end{array}$ \\
\hline Personal Income Tax & NBER & The state personal income tax rate for each state. \\
\hline Nexus-Based Corporate Tax Rate & Infogroup & $\begin{array}{l}\text { We aggregate the state corporate tax rates to the firm } \\
\text { level according to its distribution of sale and employee. } \\
\text { The company's sale share and payroll share in each state } \\
\text { are obtained from Infogroup. }\end{array}$ \\
\hline Property Apportionment & State Tax Handbook & $\begin{array}{l}\text { Weight assigned to the property factor in the apportion- } \\
\text { ment formula. The multi-state firms must apportion } \\
\text { their profits according to the formula when deciding how } \\
\text { much tax they should pay. }\end{array}$ \\
\hline Sales Apportionment & State Tax Handbook & $\begin{array}{l}\text { Weight assigned to the sales factor in the apportionment } \\
\text { formula. The multi-state firms must apportion their prof- } \\
\text { its according to the formula when deciding how much } \\
\text { tax they should pay. }\end{array}$ \\
\hline Throwback & State Tax Handbook & $\begin{array}{l}\text { Indicator of whether a state has adopted a throwback rule } \\
\text { when calculating taxable income. Under the throwback } \\
\text { rule, the state requires the firms to add sales that are to } \\
\text { buyers in a state where the company has no nexus. }\end{array}$ \\
\hline Throwout & State Tax Handbook & $\begin{array}{l}\text { Indicator of whether a state has adopted a throwout rule } \\
\text { when calculating taxable income. The sales that are to } \\
\text { buyers in a state where the company has no nexus are } \\
\text { called nowhere sales. Under a throwout rule, the state } \\
\text { requires the firms to subtract the nowhere sales from to- } \\
\text { tal sales (the denominator), and thereby increasing the } \\
\text { apportion weights. }\end{array}$ \\
\hline Property Tax Revenue & Census & Total property tax revenue in a given year. \\
\hline State Total Revenue & Census & Total state tax revenue in a given year. \\
\hline State General Revenue & Census & Total state general revenue in a given year. \\
\hline GDP & BLS & State GDP in millions of dollars. \\
\hline Unemployment Insurance Base & State UI Laws & Max wage base subject to state UI tax. \\
\hline Unemployment Insurance Rate & State UI Laws & Max UI rate at each state in a given year. \\
\hline Unemployment Rate & BLS & State unemployment rate. \\
\hline LFO & Orbis & $\begin{array}{l}\text { The legal form organization is identified by the legal } \\
\text { form information and shareholder information from the } \\
\text { Orbis database. Non-profit organizations and public au- } \\
\text { thorities are labeled firms who don/t need to pay a tax. } \\
\text { Public limited companies, and firms with more than } 100 \\
\text { shareholders or with non-natural persons as sharehold- } \\
\text { ers are identified as C corporations, leaving the rest as } \\
\text { the } S \text { corporations. }\end{array}$ \\
\hline
\end{tabular}




\section{Table A.2: Summary Statistics for Sample Construction}

This table describes the main analysis sample. It shows the number of observations after each data merge, along with the number of product codes, producers, C-Corporations and basic summary statistics for total sales.

\begin{tabular}{|c|c|c|c|c|c|c|c|c|}
\hline \multirow[t]{2}{*}{ Sample } & \multirow[t]{2}{*}{ \# Obs. } & \multirow[t]{2}{*}{ \# UPCs } & \multirow[t]{2}{*}{ \# Producers } & \multirow[t]{2}{*}{ \# C-Corps } & \multicolumn{4}{|c|}{ Total \$ Sales } \\
\hline & & & & & Mean & 25 th & Median & 75th \\
\hline Full UPC Sample & $264,194,038$ & $1,990,373$ & - & - & 8,684 & 70 & 516 & 3,243 \\
\hline Matched GS1 Sample & $227,702,908$ & $1,561,623$ & 40,183 & - & 7,871 & 65 & 483 & 2,953 \\
\hline Matched Orbis Sample & $207,795,462$ & $1,413,159$ & 32,656 & 4,996 & 7,585 & 67 & 454 & 2,984 \\
\hline Matched Infogroup Sample & $114,949,602$ & 793,801 & 14,411 & 2,894 & 7,584 & 68 & 483 & 2,984 \\
\hline Matched Control Variables & $85,920,149$ & 606,787 & 12,314 & 2,490 & 7,262 & 80 & 514 & 2,981 \\
\hline C-Corporations & $54,701,489$ & 273,185 & 2,490 & 2,490 & 7,348 & 82 & 527 & 3,041 \\
\hline C-Corporations (Dropping Singletons) & $50,525,599$ & 211,990 & 2,158 & 2,158 & 7,846 & 99 & 613 & 3,401 \\
\hline
\end{tabular}




\section{Table A.3: Summary Statistics}

This table shows summary statistics for the main analysis sample for S-Corps. Observations are at the UPC - retailer chain - sold-state - year level. The sale-weighted price is the average price of one UPC sold by a particular retailer at a state in one year, and it is weighted by the sold quantities. Tax rates are inclusive of federal taxes. The sales are the dollar sales of a UPC product sold by a retailer in a state in a given year. Other variables are defined in the Appendix Table A.1. Source: Nielsen and GS1.

\begin{tabular}{lccccc}
\hline \hline & \multicolumn{5}{c}{ S-Corp Sample } \\
& Mean & Std. Dev. & $25^{\text {th }}$ Pctl. & Median & $75^{\text {th }}$ Pctl. \\
\hline Sale-weighted Price & 5.97 & 6.94 & 2.42 & 3.87 & 6.99 \\
Corporate Tax Rate & 0.41 & 0.02 & 0.39 & 0.41 & 0.42 \\
Personal Income Tax Rate & 0.30 & 0.12 & 0.23 & 0.32 & 0.39 \\
Log(State Government's General Revenue) & 17.99 & 0.90 & 17.29 & 17.90 & 18.88 \\
Log(State Government's Total Revenue) & 18.16 & 0.97 & 17.47 & 18.06 & 19.09 \\
State's Budget Balance & -0.01 & 0.24 & -0.05 & 0.01 & 0.11 \\
Log(State GDP) & 13.36 & 0.94 & 12.60 & 13.31 & 14.21 \\
Investment & 1.42 & 2.45 & 0.00 & 0.00 & 3.00 \\
Unemployment Rate & 7.07 & 2.22 & 5.30 & 6.70 & 8.80 \\
UI Rate & 7.73 & 2.00 & 6.20 & 7.00 & 9.20 \\
UI Base Wage (Thousands) & 13.10 & 7.87 & 7.00 & 10.30 & 14.00 \\
Property Tax Share & 0.01 & 0.01 & 0.00 & 0.00 & 0.01 \\
Property Apportionment Rate & 9.75 & 12.42 & 0.00 & 0.00 & 25.00 \\
Payroll Apportionment Rate & 9.75 & 12.42 & 0.00 & 0.00 & 25.00 \\
Sales Apportionment Rate & 80.07 & 25.36 & 50.00 & 100.00 & 100.00 \\
\hline Observations & $28,919,249$ & & & & \\
\hline \hline
\end{tabular}




\section{Table A.4: Corporate Taxes and Retail Prices Using Nielsen Homescan Data}

The table replicates the analysis in Table 2 and also accounts for apportionment factors. Retail prices are measured in the geographic location where a good is sold. Corporate taxes are measured as the average tax rate weighted by the apportionment factors. The inclusion of controls and fixed effects is denoted beneath each specification. Controls include logged forms of state revenue, state GDP, the unemployment insurance base wage rate and the levels of insurance rates, state unemployment rates, and unemployment compensation. Regressions weighted by the inverse hyperbolic sine of product sales. The sample is restricted to firms that we can identify as C-corporations. We restrict the products to those that have been consumed in one retailer chain at one state for at least 24 consecutive months, to minimize the effects of rapid entry and exit of products. Standard errors are clustered at the firm year and retailer levels. Source: Nielsen and GS1. ${ }^{*} p<.1,{ }^{* *} p<.05, * * * p<.01$.

\begin{tabular}{lccccc}
\hline \hline & $(1)$ & $(2)$ & $(3)$ & $(4)$ & $(5)$ \\
& $\log ($ Price $)$ & $\log ($ Price $)$ & $\log ($ Price $)$ & $\log ($ Price $)$ & $\log ($ Price $)$ \\
\hline $\log \left(1-\tau^{c}\right)$ & $-0.217^{* *}$ & $-0.220^{* *}$ & $-0.205^{* *}$ & $-0.180^{* *}$ & $-0.194^{* *}$ \\
& $(0.0898)$ & $(0.0884)$ & $(0.0780)$ & $(0.0783)$ & $(0.0851)$ \\
\hline Controls & $\mathbf{X}$ & $\mathbf{X}$ & $\mathbf{X}$ & $\mathbf{X}$ & $\mathbf{X}$ \\
UPC $\times$ Retailer $\times$ Sold State & $\mathbf{X}$ & $\mathbf{X}$ & $\mathbf{X}$ & $\mathbf{X}$ & $\mathbf{X}$ \\
Year & $\mathbf{X}$ & & & & \\
Sold State $\times$ Year & & $\mathbf{X}$ & & $\mathbf{X}$ & \\
Retailer $\times$ Year & & & $\mathbf{X}$ & $\mathbf{X}$ & $\mathbf{X}$ \\
Sold State $\times$ Retailer $\times$ Year & & & & & 352,328 \\
Observations & 352,328 & 352,328 & 352,328 & 352,328 \\
\hline \hline
\end{tabular}


Table A.5: Corporate Taxes and Retail Prices, Alternative Tax Nexus (HQ)

The table shows the relationship between retail prices and corporate taxes. Retail prices are measured in the geographic location where a good is sold. Corporate taxes are measured based on a firm's headquarters state. The inclusion of controls and fixed effects is denoted beneath each specification. Controls include logged forms of state revenue, state GDP, the unemployment insurance base wage rate and the levels of insurance rates, state unemployment rates, and unemployment compensation. Regressions weighted by the inverse hyperbolic sine of product sales. The sample is restricted to firms that we can identify as $\mathrm{C}$-corporations and headquartered in states with corporate taxes. Standard errors are clustered at the firm year and retailer levels. Source: Nielsen and GS1. * $p<.1$, ** $p<.05$, *** $p<.01$

\begin{tabular}{lccccc}
\hline \hline & $(1)$ & $(2)$ & $(3)$ & $(4)$ & $(5)$ \\
& $\log ($ Price $)$ & $\log ($ Price $)$ & $\log ($ Price $)$ & $\log ($ Price $)$ & $\log ($ Price $)$ \\
\hline $\log \left(1-\tau^{c}\right)$ & $-0.384^{* * *}$ & $-0.377^{* * *}$ & $-0.280^{* * *}$ & $-0.278^{* * *}$ & $-0.273^{* * *}$ \\
& $(0.0704)$ & $(0.0702)$ & $(0.0718)$ & $(0.0717)$ & $(0.0715)$ \\
\hline Controls & $\mathbf{X}$ & $\mathbf{X}$ & $\mathbf{X}$ & $\mathbf{X}$ & $\mathbf{X}$ \\
UPC $\times$ Retailer $\times$ Sold State & $\mathbf{X}$ & $\mathbf{X}$ & $\mathbf{X}$ & $\mathbf{X}$ & $\mathbf{X}$ \\
Year & $\mathbf{X}$ & & & & $\mathbf{X}$ \\
Sold State $\times$ Year & & $\mathbf{X}$ & & $\mathbf{X}$ & \\
Retailer $\times$ Year & & & $\mathbf{X}$ & & $\mathbf{X}$ \\
$\begin{array}{l}\text { Sold State } \times \text { Retailer } \times \text { Year } \\
\text { Observations }\end{array}$ & $50,525,599$ & $50,525,599$ & $50,525,599$ & $50,525,599$ & $50,525,599$ \\
\hline \hline
\end{tabular}


Table A.6: Corporate Taxes and Retail Prices, Additional Fixed Effects

The table shows the relationship between retail prices and corporate taxes using OLS regressions. Retail prices are measured in the geographic location where a good is sold. Corporate taxes are measured via an estimate of tax nexus. The inclusion of controls and fixed effects is denoted beneath each specification. Controls include logged forms of state revenue, state GDP, the unemployment insurance base wage rate and the levels of insurance rates, state unemployment rates, and unemployment compensation. Regressions weighted by the inverse hyperbolic sine of product sales. The sample is restricted to firms that we can identify as C-corporations and headquartered in states with corporate taxes. Standard errors are clustered at the firm year and retailer levels. Source: Nielsen and GS1. $* p<.1, * * p<.05, * * *$ $p<.01$.

\begin{tabular}{lcccc}
\hline \hline & $\begin{array}{c}(1) \\
\log (\text { Price })\end{array}$ & $\begin{array}{c}(2) \\
\log (\text { Price })\end{array}$ & $\begin{array}{c}(3) \\
\log (\text { Price })\end{array}$ & $\begin{array}{c}(4) \\
\log (\text { Price })\end{array}$ \\
\hline $\log \left(1-\tau^{c}\right)$ & $-0.325^{* * *}$ & $-0.145^{*}$ & $-0.246^{* * *}$ & $-0.245^{* * *}$ \\
& $(0.107)$ & $(0.0859)$ & $(0.0927)$ & $(0.0925)$ \\
\hline Controls & $\mathbf{X}$ & $\mathbf{X}$ & $\mathbf{X}$ & $\mathbf{X}$ \\
UPC $\times$ Retailer $\times$ Sold State & $\mathbf{X}$ & $\mathbf{X}$ & $\mathbf{X}$ & $\mathbf{X}$ \\
Year & $\mathbf{X}$ & & & \\
Retailer $\times$ Year & & $\mathbf{X}$ & $\mathbf{X}$ & $\mathbf{X}$ \\
Retailer $\times$ Year $\times$ Sold State & & & & $\mathbf{X}$ \\
$\begin{array}{l}\text { Sold State } \times \text { Year } \\
\text { Observations }\end{array}$ & & & $50,525,599$ & $50,525,599$ \\
\hline \hline
\end{tabular}


Table A.7: Corporate Taxes and Retail Prices, Alternate Clustering

The table shows the relationship between retail prices and corporate taxes using OLS regressions. Retail prices are measured in the geographic location where a good is sold. Corporate taxes are measured via an estimate of tax nexus. The inclusion of controls and fixed effects is denoted beneath each specification. Controls include logged forms of state revenue, state GDP, the unemployment insurance base wage rate and the levels of insurance rates, state unemployment rates, and unemployment compensation. Regressions weighted by the inverse hyperbolic sine of product sales. The sample is restricted to firms that we can identify as C-corporations and headquartered in states with corporate taxes. Standard errors are clustered at the retailer level. Source: Nielsen and GS1. * $p<.1$, ** $p<.05, * * * p<.01$

\begin{tabular}{lccccc}
\hline \hline & $(1)$ & $(2)$ & $(3)$ & $(4)$ & $(5)$ \\
& $\log ($ Price $)$ & $\log ($ Price $)$ & $\log ($ Price $)$ & $\log ($ Price $)$ & $\log ($ Price $)$ \\
\hline $\log \left(1-\tau^{c}\right)$ & $-0.325^{* * *}$ & $-0.322^{* * *}$ & $-0.246^{* * *}$ & $-0.245^{* * *}$ & $-0.243^{* * *}$ \\
& $(0.0625)$ & $(0.0623)$ & $(0.0562)$ & $(0.0561)$ & $(0.0560)$ \\
\hline Controls & $\mathbf{X}$ & $\mathbf{X}$ & $\mathbf{X}$ & $\mathbf{X}$ & $\mathbf{X}$ \\
UPC $\times$ Retailer $\times$ Sold State & $\mathbf{X}$ & $\mathbf{X}$ & $\mathbf{X}$ & $\mathbf{X}$ & $\mathbf{X}$ \\
Year & $\mathbf{X}$ & & & & $\mathbf{X}$ \\
Sold State $\times$ Year & & $\mathbf{X}$ & & $\mathbf{X}$ & \\
Retailer $\times$ Year & & & $\mathbf{X}$ & & $\mathbf{X}$ \\
$\begin{array}{l}\text { Sold State } \times \text { Retailer } \times \text { Year } \\
\text { Observations }\end{array}$ & $50,525,599$ & $50,525,599$ & $50,525,599$ & $50,525,599$ & $50,525,599$ \\
\hline \hline
\end{tabular}


Table A.8: Corporate Taxes and Retail Prices, Alternate Clustering

The table shows the relationship between retail prices and corporate taxes using OLS regressions. Retail prices are measured in the geographic location where a good is sold. Corporate taxes are measured via an estimate of tax nexus. The inclusion of controls and fixed effects is denoted beneath each specification. Controls include logged forms of state revenue, state GDP, the unemployment insurance base wage rate and the levels of insurance rates, state unemployment rates, and unemployment compensation. Regressions weighted by the inverse hyperbolic sine of product sales. The sample is restricted to firms that we can identify as C-corporations and headquartered in states with corporate taxes. Standard errors are clustered at the state level. Source: Nielsen and GS1. $* p<.1, * * p<.05, * * * p<.01$.

\begin{tabular}{lccccc}
\hline \hline & $(1)$ & $(2)$ & $(3)$ & $(4)$ & $(5)$ \\
& $\log ($ Price $)$ & $\log ($ Price $)$ & $\log ($ Price $)$ & $\log ($ Price $)$ & $\log ($ Price $)$ \\
\hline $\log \left(1-\tau^{c}\right)$ & $-0.325^{* * *}$ & $-0.322^{* * *}$ & $-0.246^{* * *}$ & $-0.245^{* * *}$ & $-0.243^{* * *}$ \\
& $(0.0146)$ & $(0.0147)$ & $(0.0125)$ & $(0.0127)$ & $(0.0126)$ \\
\hline Controls & $\mathbf{X}$ & $\mathbf{X}$ & $\mathbf{X}$ & $\mathbf{X}$ & $\mathbf{X}$ \\
UPC $\times$ Retailer $\times$ Sold State & $\mathbf{X}$ & $\mathbf{X}$ & $\mathbf{X}$ & $\mathbf{X}$ & $\mathbf{X}$ \\
Year & $\mathbf{X}$ & & & & $\mathbf{X}$ \\
Sold State $\times$ Year & & $\mathbf{X}$ & & $\mathbf{X}$ & \\
Retailer $\times$ Year & & & $\mathbf{X}$ & & $\mathbf{X}$ \\
$\begin{array}{l}\text { Sold State } \times \text { Retailer } \times \text { Year } \\
\text { Observations }\end{array}$ & $50,525,599$ & $50,525,599$ & $50,525,599$ & $50,525,599$ & $50,525,599$ \\
\hline \hline
\end{tabular}




\section{Table A.9: Corporate Taxes, Retail Prices, and Debt}

The table shows the relationship between corporate taxes and retail prices across products with different debt ratio or leverage. Retail prices are measured in the geographic location where a good is sold. Corporate taxes are measured via an estimate of tax nexus. We include an interaction of corporate taxes with debt to asset ratios. We compute the debt ratio as the ratio of the sum of current and long-term liabilities over total assets. Debt information is collected from Compustat. The inclusion of controls and fixed effects is denoted beneath each specification. Controls include logged forms of state revenue, state GDP, the unemployment insurance base wage rate and the levels of insurance rates, state unemployment rates, and unemployment compensation. Regressions weighted by the inverse hyperbolic sine of product sales. The sample is restricted to firms that we can identify as C-corporations and headquartered in states with corporate taxes. Standard errors are clustered at the firm year and retailer levels. Source: Nielsen, GS1 and Compustat. ${ }^{*} p<.1, * * p<.05, * * * p<.01$.

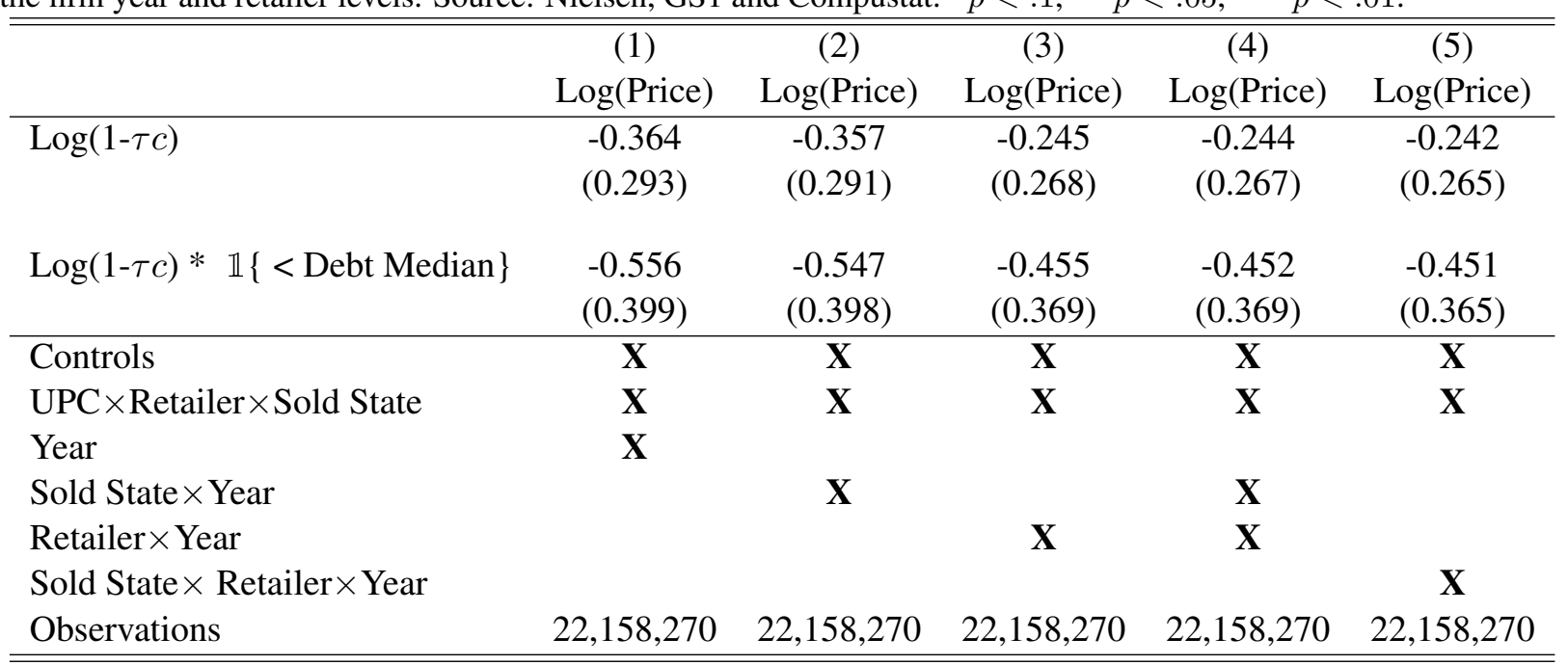




\section{Table A.10: Corporate Taxes and Product Offerings}

The table shows the relationship between log number of unique products and corporate taxes using OLS regressions. Corporate taxes are measured via an estimate of tax nexus. The inclusion of controls and fixed effects is denoted beneath each specification. Controls include logged forms of total and general state revenue, state GDP and budget balance, the unemployment insurance base wage rate and the levels of insurance rates, state unemployment rates, and unemployment compensation. Regressions weighted by the inverse hyperbolic sine of product sales. Observations in this table are firm-years. The sample is restricted to firms that we can identify as C-corporations and headquartered in states with corporate taxes. Standard errors are clustered at the firm year and retailer level. Source: Nielsen and GS1. $* p<.1, * *$ $p<.05, * * * p<.01$.

\begin{tabular}{lcccc}
\hline \hline & $(1)$ & $(2)$ & $(3)$ & $(4)$ \\
& $\ln (\#$ UPCs $)$ & $\ln ($ \# UPCs $)$ & $\ln ($ \# UPCs $)$ & $\ln (\#$ UPCs $)$ \\
\hline $\log \left(1-\tau^{c}\right)$ & $0.257^{* *}$ & $0.343^{* * *}$ & $0.251^{* *}$ & $0.332^{* * *}$ \\
& $(0.127)$ & $(0.128)$ & $(0.126)$ & $(0.128)$ \\
\hline Controls & $\mathbf{X}$ & $\mathbf{X}$ & $\mathbf{X}$ & $\mathbf{X}$ \\
Firm & $\mathbf{X}$ & $\mathbf{X}$ & $\mathbf{X}$ & $\mathbf{X}$ \\
Year & $\mathbf{X}$ & & & \\
Retailer $\times$ Year & & $\mathbf{X}$ & $\mathbf{X}$ & $\mathbf{X}$ \\
Sold State $\times$ Year & & & $\mathbf{X}$ \\
Observations & $1,599,711$ & $1,599,711$ & $1,599,711$ & $1,599,711$ \\
\hline \hline
\end{tabular}

